Article

\title{
High-Pressure Extraction of Antioxidant-Rich Fractions from Shrubby Cinquefoil (Dasiphora fruticosa L. Rydb.) Leaves: Process Optimization and Extract Characterization
}

\author{
Michail Syrpas *DD, Kiran Subbarayadu, Vaida Kitrytė and Petras Rimantas Venskutonis $\mathbb{D}$ \\ Department of Food Science \& Technology, Kaunas University of Technology, Radvilènu pl. 19, \\ LT-50254 Kaunas, Lithuania; kiran.subbarayadu@ktu.lt (K.S.); vaida.kitryte@ktu.lt (V.K.); \\ rimas.venskutonis@ktu.lt (P.R.V.) \\ * Correspondence: michail.syrpas@ktu.lt
}

Received: 9 April 2020; Accepted: 21 May 2020; Published: 26 May 2020

check for updates

\begin{abstract}
Dasiphora fruticosa (basionym Potentilla fruticosa) is a shrub, known in traditional medicine for centuries. Due to the wide range of pharmacological effects, interest and applications of $D$. fruticosa extracts are continually increasing; however, reports on optimization of extraction conditions are scarce. Herein, a multi-step high-pressure extraction process with increasing polarity solvents was developed to isolate valuable fractions from $D$. fruticosa leaves. Supercritical $\mathrm{CO}_{2}$ extraction recovered $2.46 \mathrm{~g} / 100 \mathrm{~g}$ of lipophilic fraction, rich in polyunsaturated fatty acids. Further, pressurized liquid extractions (PLE) with acetone, ethanol, and water were applied to obtain antioxidant-rich higher polarity extracts. Under optimized PLE conditions, the cumulative polar fraction yield was $29.98 \mathrm{~g} / 100 \mathrm{~g}$. Ethanol fraction showed the highest yield $(15.3 \mathrm{~g} / 100 \mathrm{~g})$, TPC values $\left(148.4 \mathrm{mg}\right.$ GAE/g), ABTS ${ }^{\bullet+}$, and $\mathrm{DPPH}^{\bullet}$ scavenging capacity (161.1 and $151.8 \mathrm{mg}$ TE/g, respectively). PLE was more efficient than conventional solid-liquid extraction in terms of extraction time, extract yields, and in vitro antioxidant capacity. Phytochemical characterization of PLE extracts by UPLC-Q-TOF-MS revealed the presence of hyperoside, ellagic acid, among other health beneficial phenolic substances. This study highlights the potential of high-pressure extraction techniques to isolate antioxidant-rich fractions from $D$. fruticosa leaves with multipurpose applications, including the prevention and treatment of chronic diseases.
\end{abstract}

Keywords: Dasiphora fruticosa; antioxidant capacity; pressurized-liquid extraction; response surface methodology; phenolic compounds; supercritical carbon dioxide extraction

\section{Introduction}

Over the last years, there have been extensive studies on the role of reactive oxygen species in several inflammatory processes and oxidative stress, and their implications to the pathogenesis of degenerative aging diseases, such as atherosclerosis, neurodegenerative illnesses, and cancer [1]. Simultaneously, interest in plant-derived phenolic substances as potential agents in the prevention and treatment of oxidative-stress related disorders has gained significant scientific attention [2]. The screening of various plants has dramatically expanded our knowledge on novel antioxidant substances, their modes of action, and roles, either as protective/prophylactic substances or as therapeutic molecules [3]. Under-investigated aromatic, ornamental flowers and medicinal plants, gained attention for their potential use as sources of nutraceuticals with bioactive properties [4]. A previous study of our group on aromatic and medicinal plants grown in Lithuania revealed that Dasiphora fruticosa (basionym Potentilla fruticosa) exerts a substantial radical scavenging activity $[5,6]$. 
D. fruticosa, commonly known as shrubby/bush cinquefoil, is a hardy deciduous flowering shrub. It is native to the cold temperate and subarctic regions of the Northern Hemisphere, often growing at high altitudes in the mountains [6]. In several parts of the world, extract preparations from aerial and underground parts of this genus are traditionally used for their antioxidant, hypoglycemic, anti-inflammatory, anti-tumor, anti-ulcerogenic, and anti-cancer properties, also for the treatment of inflammations, wounds and pathogen infections $[7,8]$. Besides traditional use, polar extracts from D. fruticosa leaves and roots find a large number of applications in the food, cosmetic, and medical industries [9]. The antimicrobial activity of D. fruticosa polar extracts against Gram-positive and Gram-negative bacteria, spore-forming bacteria, and fungi has been verified in some previous publications, indicating the potential use of these extracts as natural antimicrobial agents in various food systems $[7,8,10,11]$. A few years ago, Liu et al. and Wang et al. demonstrated that $D$. fruticosa leaf extracts when combined with green tea polyphenols or Ginkgo biloba extracts show synergistic, additive, and antagonistic effects on a variety of oxidation systems [12-14]. The reported bioactivity of these extracts is typically attributed to the high phenolic content of this plant. D. fruticosa, as several other Dasiphora genera, contains a wide range of bioactive substances [8]. Among which, flavonoids and their glycosides, hydrolyzed tannins, sterols, triterpenoids, and phenolic acids [8]. In ornamental flowers and medicinal plants, the content of antioxidant substances is constitutive and known to be influenced primarily by environmental factors [15]. Liu et al. showed that the geographic location, altitude, annual sunshine duration, and temperature, among other factors, influence the qualitative and quantitative phytochemical content of $D$. fruticosa [16,17].

Studies so far focused on the isolation and identification of bioactive substances, primarily based on conventional extraction techniques. However, modern manufacturing practices and consumer trends require the application of extraction methods with reduced environmental impact and use of renewable, non-toxic, cost-effective, readily available, food/pharmaceutical-grade solvents [18]. Supercritical carbon dioxide $\left(\mathrm{SFE}-\mathrm{CO}_{2}\right)$ and pressurized liquid extraction (PLE) are extraction techniques that fit all requirements for the green, sustainable recovery of functional components from medicinal plants [19]. Both methods are known for their shorter extraction times, with reduced solvent consumption as compared with conventional fractionation techniques. Automated high-pressure fractionation processes allow obtaining extracts with higher yields, selectivity while reducing the risk of light- or air-induced phytochemical degradation [19].

Although there is an increasing interest in the potential applications and bioactive properties of $D$. fruticosa extracts, to the best of our knowledge, there are no reports on sufficient, sustainable extraction and optimization of extraction parameters of $D$. fruticosa. This study aimed to fill this gap in research and to develop a sequential high-pressure extraction process with increasing polarity solvents to isolate antioxidant-rich extracts from $D$. fruticosa leaves. This approach could be regarded as a sustainable alternative to obtain higher added-value fractions from ornamental and medicinal plants with food, nutraceutical, and pharmaceutical applications.

\section{Materials and Methods}

\subsection{Plant Material}

Dasiphora fruticosa samples were collected at blooming stage in the summer of 2018 in the Kaunas Botanical Garden of Vytautas Magnus University, Kaunas, Lithuania ( $54^{\circ} 52^{\prime} 14^{\prime \prime}$ N/ $23^{\circ} 54^{\prime} 40^{\prime \prime}$ E). Collected raw materials were air-dried at room temperature $\left(20-25^{\circ} \mathrm{C}\right)$ in a dark, well-ventilated room. The dried leaves were subsequently ground in an ultra centrifugal mill Retsch ZM 200 at $8000 \mathrm{rpm}$ (Retsch $\mathrm{GmbH}$, Haan, Germany) using $0.5 \mathrm{~mm}$ sieve. The ground material was stored in hermetically sealed dark glass jars, in a well-ventilated storage place until further extraction and fractionation. 


\subsection{Chemicals and Reagents}

Gallic acid (3,4,5-trihydroxybenzoic acid, 99\%), 2,2-diphenyl-1-picrylhydrazyl hydrate free radical (DPPH ${ }^{\bullet}, 95 \%$ ), 2,2' -azino-bis(3-ethylbenzthiazoline-6-sulphonic acid) (ABTS), 6-hydroxy-2,5,7,8tetramethylchroman-2-carboxylic acid (Trolox, 97\%), Supelco ${ }^{\circledR} 37$ Component FAME Mix $(10 \mathrm{mg} / \mathrm{mL}$ in methylene chloride), microcrystalline cellulose $(20 \mu \mathrm{m})$, catalytic tablet $\left(3.5 \mathrm{~g} \mathrm{~K}_{2} \mathrm{SO}_{4}\right.$ and $\left.0.4 \mathrm{~g} \mathrm{CuSO}_{4}\right)$, $\mathrm{Na}_{2} \mathrm{CO}_{3}$, were purchased from Sigma-Aldrich (Steinheim, Germany). Folin-Ciocalteu's phenol reagent (2 M) was obtained from Fluka Analytical (Bornem, Belgium). $\mathrm{NaCl}, \mathrm{KCl}, \mathrm{KH}_{2} \mathrm{PO}_{4}, \mathrm{~K}_{2} \mathrm{~S}_{2} \mathrm{O}_{8}$ were from Lach-Ner (Brno, Czech Republic), $\mathrm{Na}_{2} \mathrm{HPO}_{4}$ from Merck KGaA (Darmstadt, Germany), boron trifluoride $24 \%$ methanol solution from Acros organics (Geel, Belgium), ethanol (96.3\%, agricultural origin) from Stumbras (Kaunas, Lithuania), liquid nitrogen from AGA SIA (Riga, Latvia), carbon dioxide and nitrogen gases (99.9\%) from Gaschema (Jonava region, Lithuania). All solvents for pressurized liquid extraction (PLE) and solid-liquid extraction (SLE) were of analytical grade. Chromatographic analysis was performed using LC-grade grade solvents.

\subsection{Extraction of Non-Polar and Polar Fractions of D. fruticosa}

\subsubsection{Supercritical Carbon Dioxide Extraction $\left(\mathrm{SFE}-\mathrm{CO}_{2}\right)$}

Extractions were conducted in a pilot-scale supercritical fluid extractor (Applied Separation, Allentown, PA, USA). Briefly, $2.4 \pm 0.001 \mathrm{~kg}$ of $D$. fruticosa leaves were placed in a $10 \mathrm{~L}$ extraction vessel. A surrounding heating jacket maintained the extraction vessel temperature. $\mathrm{CO}_{2}$ consumption was measured by a ball float rotameter and a digital mass flow meter in $\mathrm{SL} / \mathrm{min}$ at standard state: pressure $(\mathrm{P})=100 \mathrm{kPa}$, temperature $(\mathrm{T})=20^{\circ} \mathrm{C}$, density $(\rho)=0.0018 \mathrm{~g} / \mathrm{mL}$. The following conditions were set: extraction pressure and temperature were $45 \mathrm{MPa}$ and $60^{\circ} \mathrm{C}$, respectively. Very similar parameters have been found to ensure a high extraction yield, as per our previous investigations [20,21]. A static extraction time of $30 \mathrm{~min}$ was kept followed by $360 \mathrm{~min}$ of total dynamic extraction. The extraction yield was determined gravimetrically $( \pm 0.001 \mathrm{~g})$ and expressed as $\mathrm{g} / 100 \mathrm{~g}$ DW.

\subsubsection{Pressurized Liquid Extraction (PLE)}

For PLE, $10 \pm 0.001 \mathrm{~g}$ of $D$. fruticosa leaves were mixed with $10 \pm 0.001 \mathrm{~g}$ of diatomous earth $(100 \%$ $\mathrm{SiO}_{2}$, Dionex Corporation, Sunnyvale, $\mathrm{CA}, \mathrm{USA}$ ) and placed in $66 \mathrm{~mL}$ stainless-steel extraction cells fitted with cellulose filters (Glass Fiber-(X)-Cellulose, Dionex Corporation, Sunnyvale, CA, USA) at both ends. The cells were then placed in an ASE-350 (Thermo Scientific Dionex, Sunnyvale, CA, USA) apparatus. For all extractions, the system pressure was $10.3 \mathrm{MPa}$ with a pre-heat time of $5 \mathrm{~min}$, the cell flush volume was $100 \%$, and the total nitrogen purge time was $120 \mathrm{~s}$. PLE with acetone (PLE-Ac) and ethanol (PLE-EtOH) were optimized by changing temperatures in the range of $60-120^{\circ} \mathrm{C}$ and $40-80^{\circ} \mathrm{C}$, respectively, whereas dynamic extraction time was performed in three cycles ranging from 5 to $15 \mathrm{~min}$ each. PLE with water $\left(\mathrm{PLE}-\mathrm{H}_{2} \mathrm{O}\right.$ ) was performed at $130{ }^{\circ} \mathrm{C}$ for $45 \mathrm{~min}$ (three cycles $\times 15 \mathrm{~min}$ ).

\subsubsection{Solid-Liquid Extraction (SLE)}

SLE experiments were performed as previously described in the literature with slight modifications [22]. Briefly, $10 \pm 0.001 \mathrm{~g}$ of $D$. fruticosa leaves and $100 \mathrm{~mL}$ of solvent (solid:liquid ratio 1:10) were added in dry glass bottles and placed in a thermostatically controlled shaker ( $800 \mathrm{rpm}$ ) for $360 \mathrm{~min}$. Depending on the solvent, the following temperatures were set: $40^{\circ} \mathrm{C}$ for acetone (SLE-Ac), $60^{\circ} \mathrm{C}$ for ethanol (SLE-EtOH), and $60^{\circ} \mathrm{C}$ for water $\left(\mathrm{SLE}-\mathrm{H}_{2} \mathrm{O}\right)$. Obtained mixtures were then centrifuged at $6000 \mathrm{~g}$ for $10 \mathrm{~min}$, and supernatants were collected and dried.

\subsubsection{Soxhlet Extraction}

Soxhlet extraction with hexane was performed from $10 \pm 0.001 \mathrm{~g}$ of $D$. fruticosa leaves. In an automated Soxhlet extractor EZ100H (Behr Labor-Technik, Düsseldorf, Germany), $100 \mathrm{~mL}$ of hexane was 
added and heated under reflux $\left(68^{\circ} \mathrm{C}\right.$ at the atmospheric pressure); the rate of extraction $-1 \mathrm{cycle} / 5 \mathrm{~min}$; total extraction time- $360 \mathrm{~min}$.

For all extracts, organic solvents were evaporated to dryness in a Büchi V-850 Rotavapor R-210 (Flawil, Switzerland), $\mathrm{H}_{2} \mathrm{O}$ was removed by freeze-drying $\left(-50^{\circ} \mathrm{C}, 0.5 \mathrm{mbar}\right)$. The yield was determined gravimetrically and was expressed as $\mathrm{g} / 100 \mathrm{~g}$ DW (mean values \pm standard deviation, $\mathrm{n}=2$ ). Non-polar and polar $D$. fruticosa leaves extracts were collected in opaque glass bottles and stored at $-20^{\circ} \mathrm{C}$ until further analysis. Solid residues after each extraction were dried and kept in a dry, well-ventilated place before SLE, PLE, or the in vitro antioxidant assays.

\subsection{In Vitro Antioxidant Capacity of D. fruticosa Extracts and Solid Residues}

\subsubsection{Total Phenolic Content (TPC) by Folin-Ciocalteu's Assay}

TPC of D. fruticosa extracts was evaluated by the modified procedure of Singleton et al. [23]. A total of $150 \mu \mathrm{L}$ of sample or methanol (blank) was mixed with $750 \mu \mathrm{L}$ of Folin-Ciocalteu's reagent $(1: 9, v / v)$ and $600 \mu \mathrm{L}$ of $\mathrm{Na}_{2} \mathrm{CO}_{3}$ solution $(75 \mathrm{~g} / \mathrm{L})$, left in the dark for $2 \mathrm{~h}$. Absorbance was measured at $760 \mathrm{~nm}$ with Spectronic Genesys 8 spectrophotometer (Thermo Spectronic, Rochester, NY). The TPC was expressed as gallic acid equivalents (mg GAE/g extract or DW; mean values \pm standard deviation, $n=4)$, employing the dose-response curve for gallic acid $(0-80 \mu \mathrm{g} / \mathrm{mL})$.

\subsubsection{The $\mathrm{ABTS}^{\bullet+}$ Scavenging Assay}

Following Re et al., ABTS ${ }^{\bullet+}$ solution was prepared by mixing $50 \mathrm{~mL}$ of ABTS ( $2 \mathrm{mmol} / \mathrm{L}$ PBS (75 mmol/L; pH 7.4)) with $200 \mu \mathrm{L} \mathrm{K}_{2} \mathrm{~S}_{2} \mathrm{O}_{8}(70 \mathrm{mmol} / \mathrm{L})$ and keeping the mixture in the dark at room temperature for $15-16 \mathrm{~h}$ before use [24]. To a $1500 \mu \mathrm{L}$ of working ABTS ${ }^{\bullet+}$ radical solution $(0.700 \pm 0.010 \mathrm{AU}$ at $734 \mathrm{~nm}) 25 \mu \mathrm{L}$ of $D$. fruticosa extract, or methanol (blank) was added, the mixtures were left in the dark for $2 \mathrm{~h}$, and the absorbance was measured at $734 \mathrm{~nm}$ with Spectronic Genesys 8 spectrophotometer. TEAC $\mathrm{ABTS}_{\mathrm{A}}$ was expressed as Trolox equivalents (mg TE/g extract or DW; mean values \pm standard deviation, $n=4)$, calculated employing dose-response curves for Trolox $(0-1500 \mu \mathrm{mol} / \mathrm{L}$ methanol).

\subsubsection{The $\mathrm{DPPH}^{\bullet}$ Scavenging Assay}

The $\mathrm{DPPH}^{\bullet}$ scavenging assay was performed following the modified procedure of Brand-Williams et al. [25]. Briefly, to $1000 \mu \mathrm{L}$ of a $\approx 89.7 \mu \mathrm{mol} / \mathrm{L}(0.800 \pm 0.010 \mathrm{AU}$ at $517 \mathrm{~nm}) \mathrm{DPPH}^{\bullet}$ methanolic solution, $500 \mu \mathrm{L}$ of $D$. fruticosa extract or methanol (blank) was added. The mixtures were then left in the dark. After $2 \mathrm{~h}$, absorbance was measured at $517 \mathrm{~nm}$ with a Spectronic Genesys 8 spectrophotometer. TEAC $\mathrm{DPPH}_{\mathrm{DPH}}$ was expressed as $\mathrm{mg} \mathrm{TE} / \mathrm{g}$ extract or DW; mean values \pm standard deviation, $n=4)$, calculated using dose-response curves for Trolox $(0-50 \mu \mathrm{mol} / \mathrm{L}$ methanol).

\subsubsection{Antioxidant Capacity Assessment of Solid Substances}

Antioxidant capacity of starting plant material and residues after extraction was evaluated by the QUENCHER method [26]. For the Folin-Ciocalteu's, ABTS ${ }^{\bullet+}$ and DPPH ${ }^{\bullet}$ assays, $10 \mathrm{mg}$ of sample (solid dilutions in microcrystalline cellulose), or cellulose (blank) was used as described elsewhere [27,28]. Data were expressed as $\mathrm{mg} \mathrm{GAE} / \mathrm{g}$ or $\mathrm{mg} \mathrm{TE} / \mathrm{g}$ (mean values \pm standard deviation, $n=4)$.

\subsection{Chromatographic Analysis of D. fruticosa Extracts}

\subsubsection{Determination of Fatty Acid Composition}

The preparation of fatty acid methyl esters (FAME) was performed as previously described [29]. FAME were analyzed on an HRGC 5300 (Mega Series, Carlo Erba, Milan, Italy) gas chromatography system coupled with a flame ionization detector. The analysis was performed using an SPTM-2560 
(100 m, $0.25 \mathrm{~mm}$ (id), $0.20 \mu \mathrm{m}$ ) capillary column (Supelco, Bellefonte, PA, USA). The oven temperature was programmed from 80 to $240^{\circ} \mathrm{C}$ with a $4{ }^{\circ} \mathrm{C} / \mathrm{min}$ ramp and then held at this temperature for $5 \mathrm{~min}$. The injector's and detector's temperatures were 220 and $240{ }^{\circ} \mathrm{C}$, respectively. The injection volume was $1 \mu \mathrm{L}$, with a split ratio of 100:1. Analyses were performed with helium as a carrier gas at a constant flow rate of $20 \mathrm{~mL} / \mathrm{s}$. A standard FAME mixture of 37 fatty acids $\left(C_{8}-C_{24}\right)$ was used for compound identification. Data were presented as percentage \pm standard deviation of the total GC-FID peak area of FAME $(n=3)$.

\subsubsection{UPLC/ESI-QTOF-MS Analysis of Extracts}

Chromatographic analysis of D. fruticosa extracts was performed on an Acquity UPLC system (Waters, Milford, USA) coupled to a Bruker maXis UHR-TOF mass spectrometer and photodiode array (PDA) detectors (Bruker Daltonics, Bremen, Germany). The system was equipped with a binary solvent delivery system, an autosampler with a $10 \mu \mathrm{L}$ sample loop and a temperature-controlled column manager. Chromatographic separation of analytes was achieved with an Acquity BEH C18 column $(1.7 \mu \mathrm{m}, 50 \times 2.1 \mathrm{~mm}$, i.d.). The solvent protocol and chromatographic conditions were as described previously $[27,28]$. Tentative compound identification was carried out by comparison of the measured accurate masses and suggested chemical formulas with hits on the Metlin database and previously reported data for $D$. fruticosa extracts. The analysis was performed in triplicate.

\subsection{Experimental Design}

Response surface methodology (RSM) using central composite design (CCD) was employed to determine the effect of the selected independent variables on the PLE extract yields and total phenolic content, and to identify the optimal conditions for PLE with acetone and ethanol. The models were established, and results were analyzed using the software Design-Expert version 12.0.8.0 (Stat-Ease Inc., Minneapolis, MN, USA). All extraction experiments were performed in random order. Statistical significance of the model and each variable was determined using the Student's $t$-test ( $p$-value) at $5 \%$ probability level $(p<0.05)$. The adequacy of the model was determined by evaluating the 'lack of fit' coefficient and the Fisher test value (F-value) obtained from the analysis of variance.

\subsection{Statistical Analysis}

Mean values and standard deviations were calculated using MS Excel 2016. One-way analysis of the variance (ANOVA), followed by the Tukey's posthoc test to compare the means that showed significant variation $(p<0.05)$ was performed and calculated using GraphPad Prism software version 7.04 for Windows.

\section{Results and Discussion}

\subsection{Yields, Antioxidant Capacity, and Fatty Acid Profile of Lipophilic Substances of D. fruticosa Leaves}

In the first part of this study, non-polar constituents were isolated from D. fruticosa leaves employing supercritical carbon dioxide extraction. $\mathrm{SFE}-\mathrm{CO}_{2}$ is a non-conventional, high-pressure technique that has already found applications in food and pharmaceutical industries for the recovery of low polarity analytes from various medicinal plants [30]. $\mathrm{CO}_{2}$ is an environmentally friendly, non-toxic, non-flammable, and generally recognized as safe (GRAS) solvent [30]. To evaluate the efficiency of SFE- $\mathrm{CO}_{2}$, conventional Soxhlet extraction with hexane was chosen as a standard technique [30]. SFE- $\mathrm{CO}_{2}\left(45 \mathrm{MPa}, 60{ }^{\circ} \mathrm{C}, 360 \mathrm{~min}\right)$ showed a slightly lower yield $(2.46 \pm 0.12 \mathrm{~g} / 100 \mathrm{~g} \mathrm{DW})$ as compared to Soxhlet extraction with hexane $(2.68 \pm 0.16 \mathrm{~g} / 100 \mathrm{~g} \mathrm{DW})$. However, these differences were not statistically significant $(p>0.05)$. An advantage of $\mathrm{SFE}-\mathrm{CO}_{2}$ is the production of pure extracts as no further solvent removal is required. On the contrary, maximum allowed solvent residue limits for hexane extracts are strictly regulated (i.e., Directive 2009/32/EC). Generally, the total essential oil or lipophilic product yields from medicinal plants are substantially lower as compared to polar solvent 
fractions. For example, Miliauskas et al. using tert-butyl methyl ether reported that the non-polar fraction yield $(0.26 \%)$ from $D$. fruticosa blossoms was significantly lower as compared to ethanol (22.3\%) and water fractions (20.3\%) that were subsequently prepared [6].

In the next step, SFE-CO $\mathrm{CO}_{2}$ extracts were analyzed by GC-FID to determine the fatty acid composition of triacylglycerols present in the extract (Figure 1). The oil was characterized by the presence of unsaturated fatty acids (total content $\approx 70 \%$ of fatty acids), and more specifically, high contents of linolenic $(29.40 \%)$, linoleic $(14.94 \%)$, and oleic (5.79\%) acids. Although there are not much data in the literature for the fatty acid profile of Dasiphora genera oils, this is in agreement with a previous study, where authors reported that the same fatty acids along with palmitic acid were the major constituents of an SFE- $\mathrm{CO}_{2}$ extract of Potentilla erecta [31].

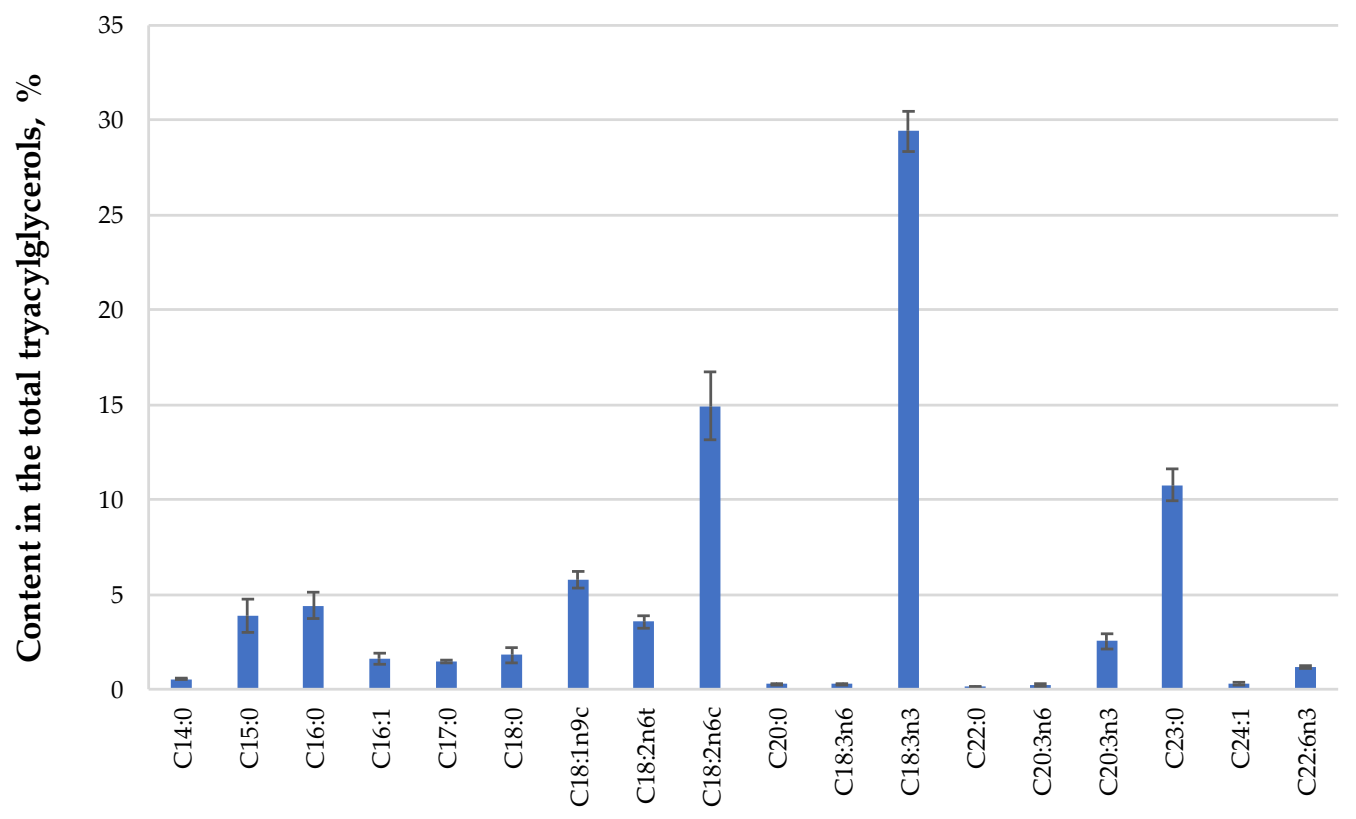

Fatty acid

Figure 1. The fatty acid composition of Dasiphora fruticosa leaves oil extract extracted by supercritical carbon dioxide $\left(\mathrm{SFE}-\mathrm{CO}_{2}\right)\left(45 \mathrm{MPa}, 60^{\circ} \mathrm{C}, 360 \mathrm{~min}\right)$, expressed as percentage \pm standard deviation of the total GC-FID peak area of fatty acid methyl esters (FAME) $(n=3)$.

Three different assays assessed the in vitro antioxidant capacity of the starting plant material and the defatted fractions: the TPC assay performed with Folin-Ciocalteu's reagent, the DPPH ${ }^{\bullet}$ scavenging assay, and the $\mathrm{ABTS}^{\bullet+}$ decolorization assay (Table 1). However, it should be noted that Folin-Ciocalteu's reagent is non-specific to phenolic compounds, and it is known to react with a wide range of reducing substances and a series of other groups of compounds. The expression of results as gallic acid equivalents thus provides an estimate of the reducing capacity of the sample and should not be considered as a direct quantitative tool of phenolic compounds.

Typically, the available literature data for Dasiphora genera are related to the antioxidant capacity of extractable plant constituents. However, a significant portion of antioxidant substances can be chemically bound to the matrix, which can result in underestimation of the total antioxidant capacity of the sample. To overcome this issue, Gökmen et al. suggested the QUENCHER approach, which evaluates the antioxidant potential of unextracted solid biomaterials and is, in principle, compatible with all the widely utilized in vitro antioxidant capacity assessment protocols [26]. This methodology is useful to evaluate the efficiency of any extraction technique with regards to the recovery of antioxidant components, indicating the necessity of further processing. It may be observed (Table 1) that the effect

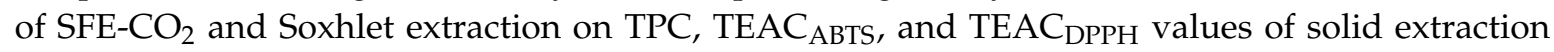
residues in most cases was not significant. 
Table 1. Yields (g/100 g), total phenolic content (TPC, $\mathrm{mg} \mathrm{GAE} / \mathrm{g}), \mathrm{ABTS}^{\bullet+}$, and $\mathrm{DPPH}^{\bullet}$ scavenging capacity (TEAC, mg TE/g) of D. fruticosa leaves solid residues after $\mathrm{SFE}-\mathrm{CO}_{2}$ and Soxhlet extractions.

\begin{tabular}{ccccc}
\hline Sample & $\begin{array}{c}\text { Yield, } \\
\text { g/100 g DW }\end{array}$ & $\begin{array}{c}\mathbf{1}^{\mathbf{T P C}} \\
\text { mg GAE/g DW }^{\mathbf{1}}\end{array}$ & $\begin{array}{c}\text { TEAC }_{\text {ABTS, }} \\
\text { mg TE/g DW }^{\mathbf{1}}\end{array}$ & $\begin{array}{c}\text { TEAC }_{\text {DPPH, }} \\
\text { mg TE/g DW }^{\mathbf{1}}\end{array}$ \\
\hline Starting plant material $^{2}$ & $-\mathrm{na}$ & $200.57 \pm 4.30^{\mathrm{a}}$ & $255.84 \pm 8.65^{\mathrm{b}}$ & $164.50 \pm 8.14^{\mathrm{a}}$ \\
Residue after SFE-CO $_{2}{ }^{2}$ & $97.54^{*}$ & $228.49 \pm 5.28^{\mathrm{b}}$ & $247.37 \pm 4.43^{\mathrm{ab}}$ & $183.63 \pm 5.00^{\mathrm{b}}$ \\
Residue after Soxhlet-He $^{3}$ & $97.32^{*}$ & $194.47 \pm 3.88^{\mathrm{a}}$ & $232.83 \pm 13.43^{\mathrm{a}}$ & $153.38 \pm 7.68^{\mathrm{a}}$ \\
\hline
\end{tabular}

1: Yield, TPC, and TEAC values, expressed per mass unit of unextracted D. fruticosa leaves; ${ }^{2}$ : SFE-CO $\mathrm{CO}_{2}$ performed at $45 \mathrm{MPa}, 60{ }^{\circ} \mathrm{C}, 360 \mathrm{~min} ;{ }^{3}$ : Soxhlet extraction performed at atmospheric pressure $(0.1 \mathrm{Mpa}), 68{ }^{\circ} \mathrm{C}, 360 \mathrm{~min}$; $*$ : Yield solid residue $=100-$ Yield $_{\text {non-polar extract }}, \mathrm{g} / 100 \mathrm{~g}$ DW. He: hexane; $\mathrm{SFE} \mathrm{CO}_{2}$ : supercritical carbon dioxide extraction; TEAC: Trolox equivalent antioxidant capacity; TPC: total phenolic content. Different superscript letters within the same column indicate significant differences (one-way ANOVA and Tukey's test. $p<0.05$ ).

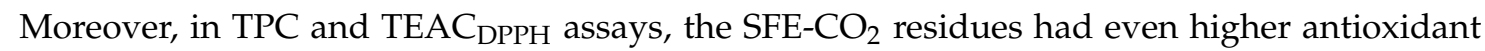
capacity than the initial material, most likely due to the removal of less active lipophilic compounds or by making bound antioxidants better accessible for reaction in the applied assays. Thus, defatted leaves retained a considerable amount of bioactive compounds with $97 \%-114 \%, 91 \%-97 \%$, and $93 \%-112 \%$ of the initial $\mathrm{TPC} \mathrm{ABTS}^{\bullet+}$, and $\mathrm{DPPH}{ }^{\bullet}$ scavenging capacity, respectively. Consequently, those fractions remain of great interest for further processing with higher polarity solvents to obtain antioxidant-rich fractions from $D$. fruticosa leaves.

\subsection{Extraction of Semi-Polar and Polar Constituents from D. fruticosa Leaves}

Antioxidant-rich SFE- $\mathrm{CO}_{2}$ residue (Table 1) of $D$. fruticosa leaves were further subjected to sequential 3-step PLE with increasing polarity solvents acetone, ethanol, and water in order to isolate semi-polar and polar compounds with potential antioxidant capacity (Supplementary Material, Figure S1). According to the EU Directive 2009/32/EC and European Medicines Agency guidelines for residual solvents EMA/CHMP/ICH/82260/2006, both acetone and ethanol can be used to process raw materials into foodstuffs, food components, or ingredients. These solvents can also be used to produce pharmaceuticals in compliance with a good manufacturing practice. Since the differences in matrix composition and process parameters may significantly influence the effectiveness of the sequential high-pressure extraction, PLE should be optimized for each plant material [19]. Response surface methodology (RSM) with central composite design (CCD) has been extensively applied as a reliable mathematical modeling method to optimize multiple-response processes over the last years. For comparison purposes, isolation of semi-polar and polar fractions from $D$. fruticosa leaves after $\mathrm{SFE}-\mathrm{CO}_{2}$ was also performed via conventional SLE (Supplementary Material, Figure S1).

\subsubsection{PLE-Ac Optimization and Model Analysis}

At the 1st step of sequential PLE, acetone was chosen as a solvent. The CCD matrix consisting of 13 experimental runs (four factorial, four axial, and five center points) is presented in Table 2 . PLE parameters such as temperature $\left(T=60-120^{\circ} \mathrm{C}\right)$ and time $(\tau=15-45 \mathrm{~min})$ were optimized to isolate antioxidant-rich acetone fractions from the SFE- $\mathrm{CO}_{2}$ residue. Two response factors (RF) were taken into consideration, the PLE-Ac yield $\left(\mathrm{RF}_{\mathrm{I}}\right)$ and the total phenolic content of the obtained extracts $\left(\mathrm{RF}_{\mathrm{II}}\right)$. As reported in Table 2, the yield of acetone-soluble components ranged from 7.05 to $16.47 \mathrm{~g}$ whereas the TPC of the obtained extracts ranged from 36.05 to $75.02 \mathrm{mg} \mathrm{GAE} / \mathrm{g}$.

Statistical evaluation of the PLE-Ac experimental design is presented in the supplementary material of this manuscript (Supplementary Material, Table S1). The analysis showed that both models were significant $(p<0.0001)$ with non-significant "lack of fit" $(p>0.05)$. Moreover, both models could be considered as reasonably reproducible, as indicated by their coefficients of variation (Supplementary Material, Table S1). 
Table 2. Central composite design matrix for the pressurized liquid extraction with acetone (PLE-Ac) optimization of $D$. fruticosa leaves after SFE- $\mathrm{CO}_{2}\left(45 \mathrm{MPa}, 60{ }^{\circ} \mathrm{C}, 360 \mathrm{~min}\right)$ and values of observed response factors $\mathrm{RF}_{\mathrm{I}}$ (PLE-Ac extract yield, $\mathrm{g} / 100 \mathrm{~g}$ of residue after $\mathrm{SFE}-\mathrm{CO}_{2}$ ) and $\mathrm{RF}_{\mathrm{II}}(\mathrm{TPC}, \mathrm{mg} \mathrm{GAE} / \mathrm{g}$ of pomace residue after SFE- $\mathrm{CO}_{2}$ ).

\begin{tabular}{|c|c|c|c|c|}
\hline \multirow{2}{*}{ Levels and Runs } & \multicolumn{2}{|c|}{ Extraction Variables } & \multirow{2}{*}{$\begin{array}{l}\text { PLE-Ac Yield, } \\
\text { g/100 g * }\end{array}$} & \multirow{2}{*}{$\begin{array}{c}\text { TPC, } \\
\text { mg GAE/g ** }\end{array}$} \\
\hline & $\tau, \min$ & $\mathrm{T},{ }^{\circ} \mathrm{C}$ & & \\
\hline Low level (-1) & 15 & 60 & & \\
\hline Medium level (0) & 30 & 90 & & \\
\hline Max level (+1) & 45 & 120 & & \\
\hline 1 (central) & 30 & 90 & $12.45 \pm 0.07$ & $46.41 \pm 0.81$ \\
\hline 2 (central) & 30 & 90 & $12.61 \pm 0.42$ & $47.78 \pm 0.60$ \\
\hline 3 (central) & 30 & 90 & $12.69 \pm 0.12$ & $48.49 \pm 0.18$ \\
\hline 4 (factorial) & 30 & 60 & $9.98 \pm 0.11$ & $60.69 \pm 0.50$ \\
\hline 5 (axial) & 15 & 60 & $7.05 \pm 0.60$ & $56.48 \pm 0.37$ \\
\hline 6 (axial) & 45 & 60 & $11.00 \pm 0.20$ & $75.02 \pm 0.27$ \\
\hline 7 (axial) & 45 & 120 & $16.47 \pm 0.19$ & $36.05 \pm 0.05$ \\
\hline 8 (factorial) & 45 & 90 & $14.32 \pm 0.80$ & $58.15 \pm 0.58$ \\
\hline 9 (axial) & 15 & 120 & $14.20 \pm 0.50$ & $48.29 \pm 0.68$ \\
\hline 10 (central) & 30 & 90 & $12.54 \pm 0.80$ & $48.55 \pm 0.63$ \\
\hline 11 (factorial) & 30 & 120 & $15.37 \pm 0.40$ & $39.69 \pm 0.10$ \\
\hline 12 (factorial) & 15 & 90 & $10.30 \pm 0.39$ & $49.22 \pm 0.16$ \\
\hline 13 (central) & 30 & 90 & $12.01 \pm 0.13$ & $48.71 \pm 0.71$ \\
\hline
\end{tabular}

*: yields expressed as $\mathrm{g} / 100 \mathrm{~g}$ of $D$. fruticosa leaves after $\mathrm{SFE}-\mathrm{CO}_{2}\left(45 \mathrm{MPa}, 60^{\circ} \mathrm{C}, 360 \mathrm{~min}\right) ;{ }^{* *}$ : TPC expressed as mg GAE/g of $D$. fruticosa leaves after SFE-CO ${ }_{2}\left(45 \mathrm{MPa}, 60{ }^{\circ} \mathrm{C}, 360 \mathrm{~min}\right) ;$ Ac: acetone; SFE-CO ${ }_{2}$ : supercritical carbon dioxide extraction; PLE: pressurized liquid extraction ( $\mathrm{P}=10.3 \mathrm{MPa})$; GAE: gallic acid equivalents; TPC: total phenolic content; $\tau$ : time; T: temperature.

ANOVA indicated that the extraction temperature (T) was the most influential parameter for both RFs (Supplementary Material, Table S1). As depicted in 3D and 2D response surface plots (Figure 2), change of extraction temperature from 60 to $120^{\circ} \mathrm{C}$ exerted dual effects: positive for PLE-Ac extract yield (from 1.5 to 2-fold increase), however negative for TPC (from 1.2 to 2-fold decrease). In the Pareto chart, it can be seen that $\approx 55 \%-60 \%$ of the observed responses for both RFs derives from the effects of $\mathrm{T}$, while the contribution of other factors is remarkably smaller (Supplementary Material, Figure S2). As presented in Figure 2, the change in PLE time from 15 to $45 \mathrm{~min}$ significantly augmented acetone-soluble component yield by $59 \%$ and TPC content by $33 \%$ at temperatures lower than $65{ }^{\circ} \mathrm{C}$. The prolonged extraction time exerted a less prominent positive effect at the average temperature interval of $65-90{ }^{\circ} \mathrm{C}$ (up to $39 \%$ and $18 \%$ increase in yield and TPC values, respectively), and further reduced TPC by $25 \%$ at the maximum PLE temperature levels (Figure 2).

The overall process for both RFs can be summarized in the following second-order polynomial regression equations:

$$
\begin{aligned}
& \text { Yield }_{P L E-A c}=12.51+1.71 \times \tau+3.00 \times \mathrm{T}-0.42 \times \tau \mathrm{T}-0.32 \times \tau^{2}+0.05 \times \mathrm{T}^{2}, \\
& \mathrm{TPC}_{P L E-A c}=48.25+2.54 \times \tau-11.36 \times \mathrm{T}-7.69 \times \tau \mathrm{T}+4.77 \times \tau^{2}+1.27 \times \mathrm{T}^{2},
\end{aligned}
$$

Considering all observed responses, within the selected range of variables, $62{ }^{\circ} \mathrm{C}$ and $45 \mathrm{~min}$ were selected as the optimal PLE-Ac conditions to isolate a semi-polar fraction of the highest in vitro antioxidant capacity from $D$. fruticosa leaves. Under this temperature and time combination, $11.67 \pm 0.13 \mathrm{~g}$ of acetone-soluble substances were recovered from $100 \mathrm{~g}$ of plant material residue after SFE- $\mathrm{CO}_{2}$, containing $75.96 \pm 1.92 \mathrm{mg} \mathrm{GAE} / \mathrm{g}$ of TPC. When per crude (unextracted) plant material was recalculated, the yield was $11.38 \pm 0.12 \mathrm{~g} / 100 \mathrm{~g}$, and the TPC was $74.07 \pm 1.87 \mathrm{mg}$ GAE/g DW. 

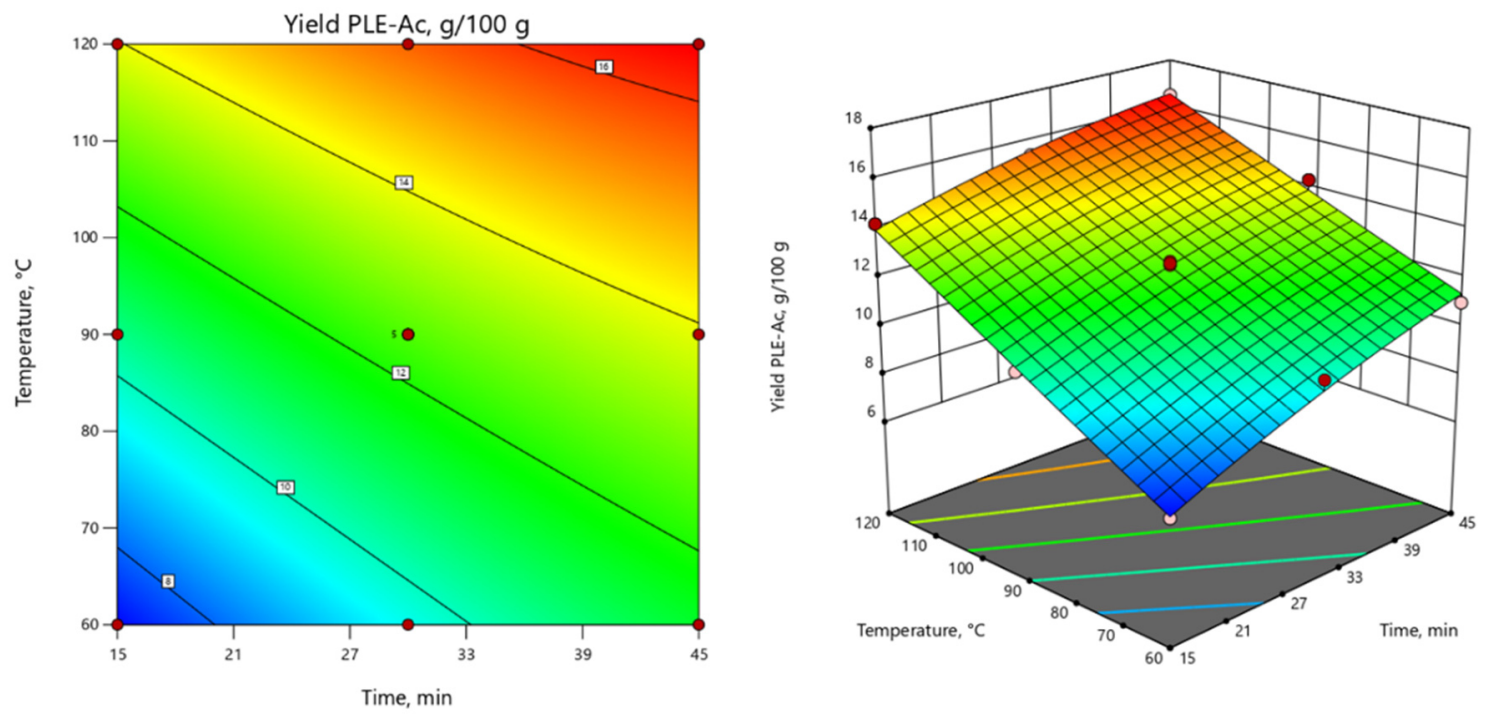

(a) Effect of time and temperature on the RFI: PLE-Ac extract yield, g/100 g residue after SFE-CO 2
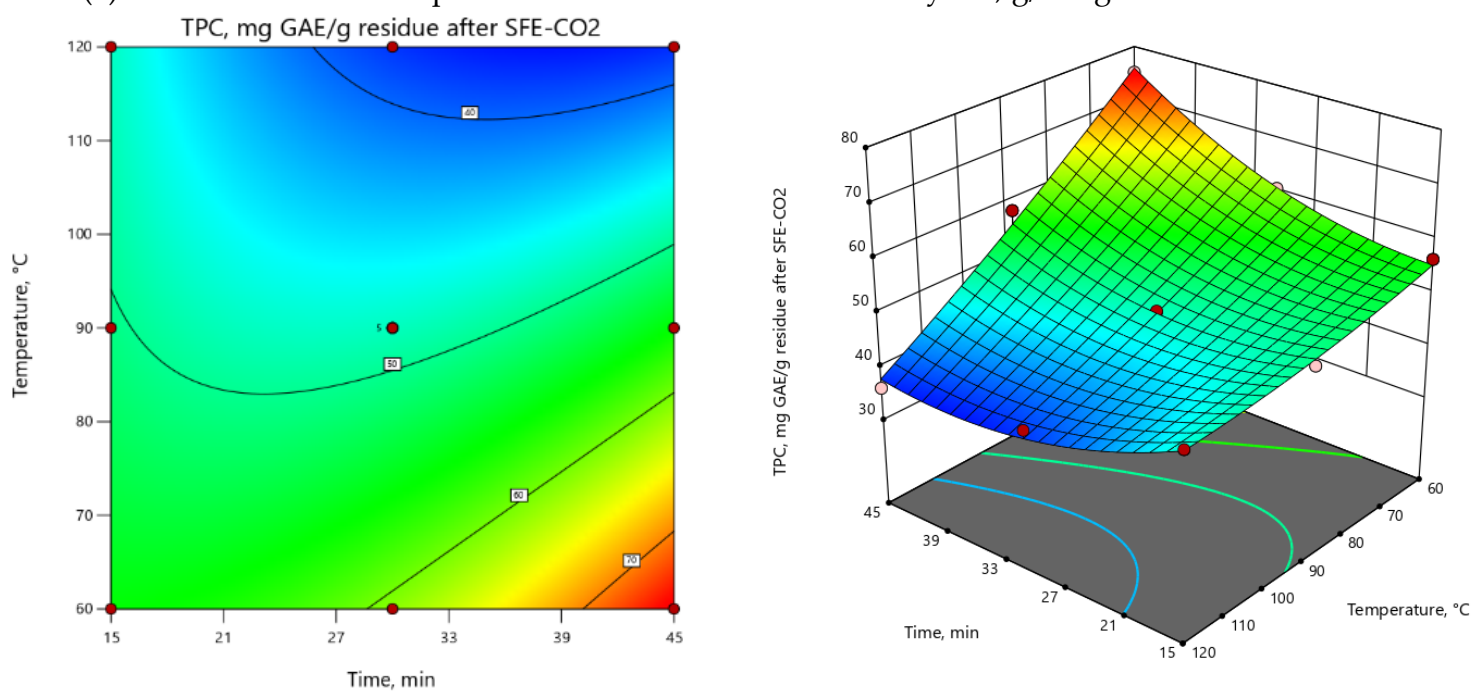

(b) Effect of time and temperature on the RFII: TPC, mg GAE/g residue after SFE-CO 2

Figure 2. Response surface $3 \mathrm{D}$ and $2 \mathrm{D}$ plots showing the effects of independent variables on the selected response factors: (a) D. fruticosa leaves PLE-Ac extract yield ( $\mathrm{g} / 100 \mathrm{~g}$ residue after $\mathrm{SFE}-\mathrm{CO}_{2}$ ); (b) total phenolic content (TPC, mg GAE/g residue after $\mathrm{SFE}-\mathrm{CO}_{2}$ ).

\subsubsection{PLE-EtOH Optimization and Model Analysis}

Isolation of ethanol-soluble fraction with the highest antioxidant capacity from $D$. fruticosa leaves residue after optimized PLE-Ac $\left(62{ }^{\circ} \mathrm{C}, 45 \mathrm{~min}\right)$ was set as the main objective for the 2 nd step of sequential PLE. For these purposes, the impact of PLE-EtOH temperature $\mathrm{T}\left(40-80{ }^{\circ} \mathrm{C}\right)$ and time $\tau$ (15-45 min) on two response factors, namely PLE-EtOH yield $\left(\mathrm{RF}_{\mathrm{I}}\right)$ and TPC of these extracts $\left(\mathrm{RF}_{\mathrm{II}}\right)$, was determined via CCD-RSM (Table 3). 
Table 3. Central composite design matrix for the pressurized liquid extraction with ethanol (PLE-EtOH) optimization of $D$. fruticosa leaves after PLE-Ac $\left(10.3 \mathrm{MPa}, 62{ }^{\circ} \mathrm{C}, 45 \mathrm{~min}\right)$ and values of observed response factors $\mathrm{RF}_{\mathrm{I}}$ (PLE-EtOH extract yield, $\mathrm{g} / 100 \mathrm{~g}$ of residue after PLE-Ac) and $\mathrm{RF}_{\mathrm{II}}(\mathrm{TPC}, \mathrm{mg} \mathrm{GAE} / \mathrm{g}$ of pomace residue after PLE-Ac).

\begin{tabular}{|c|c|c|c|c|}
\hline \multirow{2}{*}{ Levels and Runs } & \multicolumn{2}{|c|}{ Extraction Variables } & \multirow{2}{*}{$\begin{array}{l}\text { PLE-EtOH Yield, } \\
\mathrm{g} / 100 \mathrm{~g} \text { * }\end{array}$} & \multirow{2}{*}{$\begin{array}{c}\text { TPC, } \\
\text { mg GAE/g ** }\end{array}$} \\
\hline & $\tau, \min$ & $\mathrm{T},{ }^{\circ} \mathrm{C}$ & & \\
\hline Low level (-1) & 15 & 40 & & \\
\hline Medium level (0) & 30 & 60 & & \\
\hline Max level (+1) & 45 & 80 & & \\
\hline 1 (central) & 30 & 60 & $12.90 \pm 0.33$ & $130.13 \pm 3.16$ \\
\hline 2 (factorial) & 30 & 40 & $8.84 \pm 0.30$ & $75.64 \pm 0.43$ \\
\hline 3 (central) & 30 & 60 & $13.37 \pm 0.25$ & $125.66 \pm 1.60$ \\
\hline 4 (axial) & 15 & 80 & $14.94 \pm 0.40$ & $86.63 \pm 0.49$ \\
\hline 5 (axial) & 15 & 40 & $7.52 \pm 0.45$ & $60.57 \pm 2.50$ \\
\hline 6 (factorial) & 15 & 60 & $11.10 \pm 1.63$ & $78.92 \pm 2.93$ \\
\hline 7 (central) & 30 & 60 & $13.01 \pm 0.13$ & $127.91 \pm 5.71$ \\
\hline 8 (factorial) & 30 & 80 & $15.25 \pm 0.36$ & $129.03 \pm 3.26$ \\
\hline 9 (axial) & 45 & 40 & $13.13 \pm 0.60$ & $131.33 \pm 0.40$ \\
\hline 10 (central) & 30 & 60 & $12.83 \pm 0.35$ & $135.99 \pm 5.73$ \\
\hline 11 (factorial) & 45 & 60 & $17.16 \pm 0.80$ & $173.20 \pm 0.37$ \\
\hline 12 (central) & 30 & 60 & $13.32 \pm 0.25$ & $127.89 \pm 3.95$ \\
\hline 13 (axial) & 45 & 80 & $18.06 \pm 0.30$ & $183.46 \pm 1.19$ \\
\hline
\end{tabular}

*: yields expressed as $\mathrm{g} / 100 \mathrm{~g}$ of $D$. fruticosa leaves after optimized PLE-Ac (10.3 MPa, $\left.62{ }^{\circ} \mathrm{C}, 45 \mathrm{~min}\right)$; **: TPC expressed as mg GAE/g of $D$. fruticosa leaves after optimized PLE-Ac (10.3 MPa, $\left.62{ }^{\circ} \mathrm{C}, 45 \mathrm{~min}\right)$; Ac: acetone; EtOH: ethanol; GAE: gallic acid equivalents; PLE: pressurized liquid extraction ( $\mathrm{P}=10.3 \mathrm{MPa})$; TPC: total phenolic content; $\tau$ : time; T: temperature.

Different temperature and time combinations yielded 7.52-18.06 g/100 g of ethanol-soluble constituents, while the obtained TPC values were in the range of 75.64-183.46 mg GAE per $1 \mathrm{~g}$ of PLE-Ac residue (Table 3). Experimentally obtained and predicted values were in good agreement for both response factors, as confirmed by the determination coefficients $R^{2}\left(R F_{I}: 0.99 ; F_{I I}: 0.98\right)$, adjusted $R^{2}\left(R F_{I}: 0.98 ; R F_{I I}: 0.96\right)$, and predicted $R^{2}\left(R F_{I}: 0.90 ; R F_{I I}: 0.85\right)$. Based on the ANOVA results, both models were significant $\left(p<0.0001 ; \mathrm{F}_{\mathrm{RFI}}=111.11, \mathrm{~F}_{\mathrm{RFII}}=60.75\right)$ and reproducible $(\mathrm{CV}$ of $3.24 \%$ and $5.93 \%$ for $\mathrm{RF}_{\mathrm{I}}$ and $\mathrm{RF}_{\mathrm{II}}$, respectively), also "lack of fit" was not significant with $p>0.05$ (Supplementary Material, Table S2). 3D and 2D response surface plots (Figure 3) show that the maximum PLE-EtOH yield and TPC values are obtained extracting samples at the high temperature $\left(>75^{\circ} \mathrm{C}\right)$ and prolonged extraction time ( $45 \mathrm{~min}$ ) combinations. The main effects of PLE parameters and their interactions are also summarized in the Pareto chart (Supplementary Material, Figure S3): $\approx 75 \%$ of the observed responses for both RFs derives from the effects of $\mathrm{T}$ and $\tau$. In comparison, the contribution of other factors is remarkably smaller $(<25 \%)$.

Second-order polynomial regression equations (in terms of coded factors) for both RFs are the following:

$$
\begin{gathered}
\text { Yield }_{P L E-E t O H}=13.04+2.46 \times \tau+3.13 \times \mathrm{T}-0.62 \times \tau \mathrm{T}+1.20 \times \tau^{2}-0.88 \times \mathrm{T}^{2}, \\
\mathrm{TPC}_{P L E-E t O H}=127.22+43.64 \times \tau+21.93 \times \mathrm{T}+6.52 \times \tau \mathrm{T}+4.57 \times \tau^{2}-19.16 \times \mathrm{T}^{2},
\end{gathered}
$$

PLE-EtOH under the selected optimal temperature $\left(75^{\circ} \mathrm{C}\right)$ and time $(45 \mathrm{~min})$ allowed to recover a substantial portion $(17.76 \pm 0.38 \mathrm{~g} / 100 \mathrm{~g})$ of ethanol-soluble components with potent in vitro antioxidant capacity $(172.29 \pm 3.30 \mathrm{mg} \mathrm{GAE} / \mathrm{g})$ from the $D$. fruticosa leave residue after PLE-Ac. When per crude (unextracted) plant material was recalculated, these PLE-EtOH yield and TPC values were equal to $15.30 \pm 0.33 \mathrm{~g} / 100 \mathrm{~g}$ and $148.40 \pm 2.84 \mathrm{mg} \mathrm{GAE} / \mathrm{g} \mathrm{DW}$, respectively. 

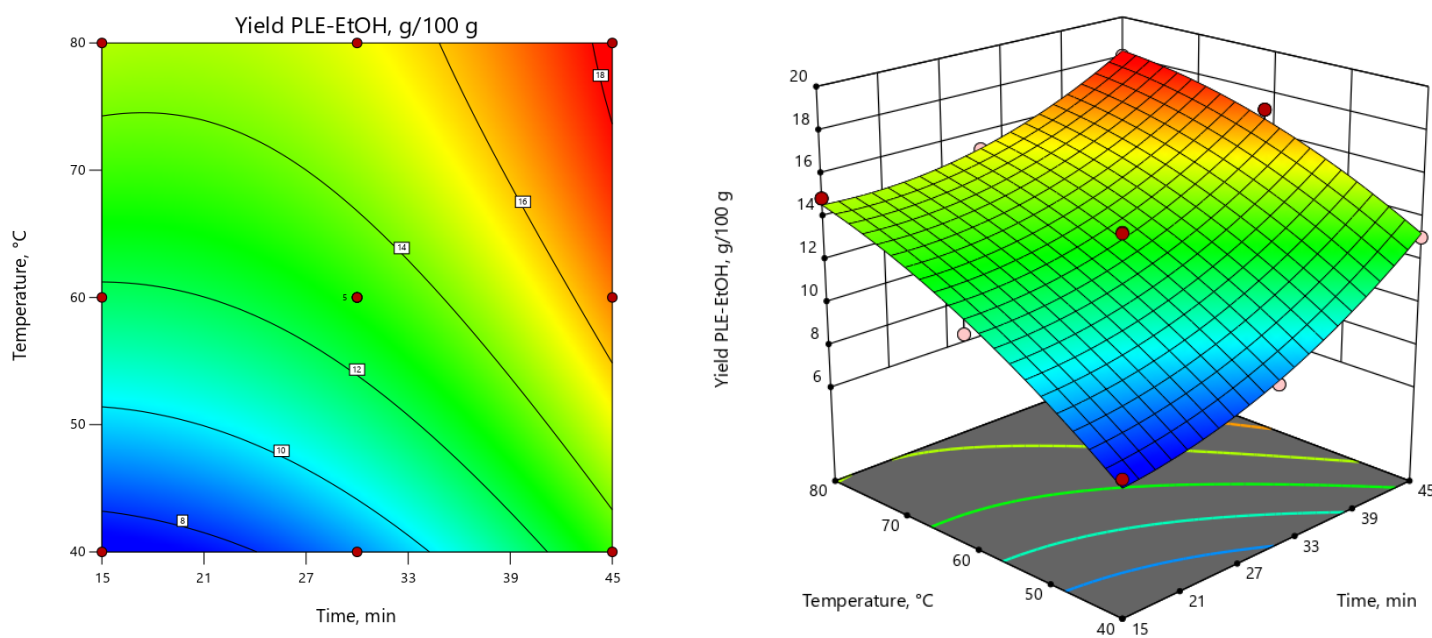

(a) Effect of time and temperature on the RFI: PLE-EtOH extract yield, g/100 g residue after PLE-Ac
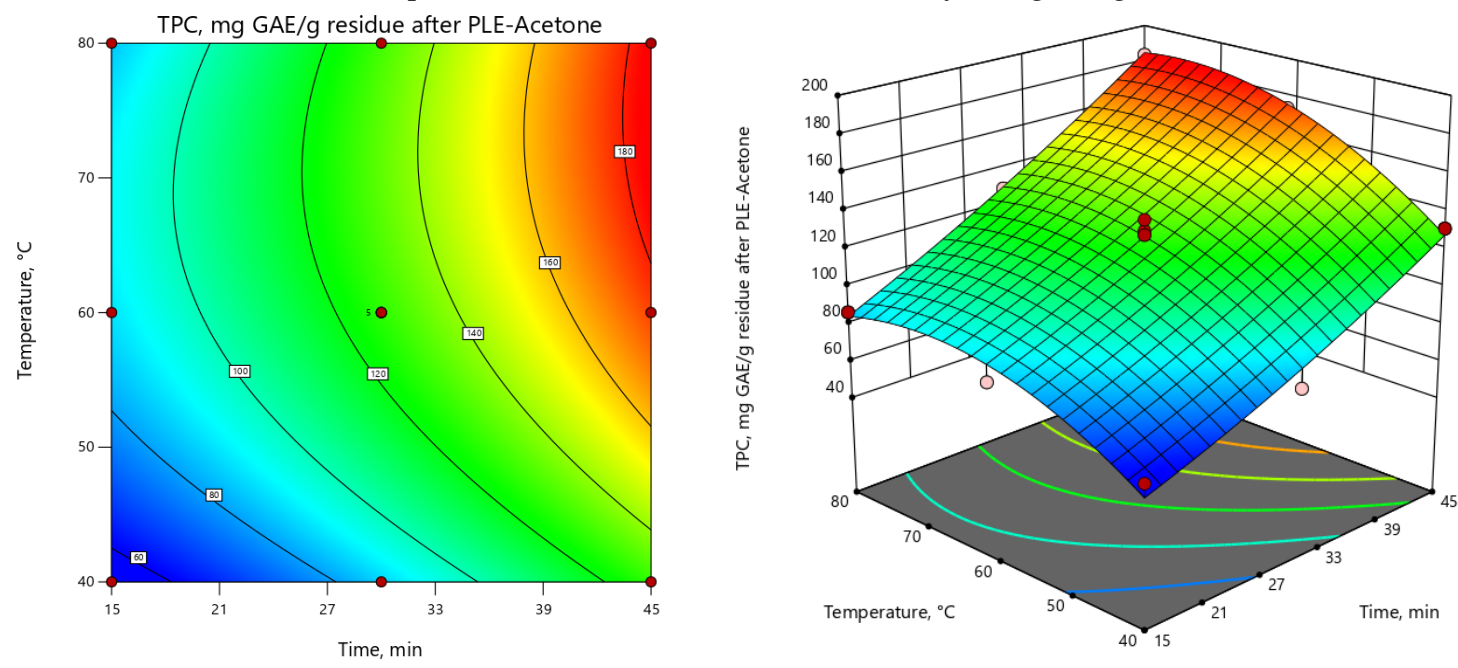

(b) Effect of time and temperature on the RFII: TPC, mg GAE/g residue after PLE-Ac

Figure 3. Response surface $3 \mathrm{D}$ and $2 \mathrm{D}$ plots showing the effects of independent variables on the selected response factors: (a) D. fruticosa leaves PLE-EtOH extract yield (g/100 g residue after PLE-Ac); (b) total phenolic content (TPC, mg GAE/g residue after PLE-Ac).

\subsubsection{Comparison of the Extraction Efficiency of PLE and Conventional Techniques}

The in vitro antioxidant capacity of solid residue after sequential extractions with $\mathrm{CO}_{2}$, acetone, and ethanol was evaluated (Table 4). The results indicate that a small portion of antioxidant substances $(10 \%-15 \%)$ remains in the matrix (Table 4$)$. Therefore, the extraction scheme was expanded by introducing an additional step in PLE with a solvent of higher polarity (water). In this case, however, temperature and time optimization for $\mathrm{PLE}-\mathrm{H}_{2} \mathrm{O}$ was not performed as (a) the residual plant material activity was low; (b) the measured antioxidant capacity also derives from cell-wall bound substances, which are difficult to extract. Under the tested conditions $\left(130{ }^{\circ} \mathrm{C}, 45 \mathrm{~min}\right), \mathrm{PLE}-\mathrm{H}_{2} \mathrm{O}$ yielded $19.42 \pm 0.62 \mathrm{~g} / 100 \mathrm{~g}$ of residue after PLE-EtOH or $13.76 \pm 0.44 \mathrm{~g} / 100 \mathrm{~g}$ DW of unextracted leaves. To evaluate the efficiency of PLE, $D$. fruticosa residues after SFE- $\mathrm{CO}_{2}$ were also subjected to conventional SLE with acetone, ethanol, and water (Supplementary Material, Figure S1).

Regardless of the applied technique, extraction yields were higher for ethanolic extracts followed by water and then acetone (Table 4). PLE-Ac yield was $\approx 68 \%$ higher than SLE: 11.38 and $6.79 \mathrm{~g} / 100 \mathrm{~g}$ DW, respectively. For ethanol, although statistically insignificant $(p>0.05)$, PLE showed a relatively small increase as compared to SLE: 15.30 versus $14.86 \mathrm{~g} / 100 \mathrm{~g}$ DW. In the last step of the extraction process performed with water as a solvent, the yield was 13.76 and $8.33 \mathrm{~g} / 100 \mathrm{~g}$ DW for PLE- $\mathrm{H}_{2} \mathrm{O}$ and SLE, 
respectively (Table 4). Overall, in terms of yield, the total cumulative yield of the polar PLE extracts under optimal conditions was $40.44 \mathrm{~g} / 100 \mathrm{~g}$ DW (94.2\% of the total extracted substances), whereas for the conventional SLE-29.98 g/ $100 \mathrm{~g}$ DW (92.4\% of the total extracted substances). These results are in line with the previous report of Miliauskas et al., where the polar fraction (ethanol and water in this case) constituted $\approx 95 \%$ of total extractable material [6]. In this study, the application of sequential high-pressure extraction improved the total polar fractions yield by $\approx 35 \%$. Moreover, the higher efficiency was achieved in significantly shorter extraction times: $135 \mathrm{~min}$ in total for the sequential high-pressure extraction as compared to the $1080 \mathrm{~min}$ for the SLE. Although there are no previous data for PLE of Dasiphora genera, thus direct comparison cannot be made, these findings are in line with previous publications for other medicinal plants. In these cases, too, the application of PLE resulted in significant yield improvement with lower extraction times and solvent consumption [30,32]. Overall, in terms of yield, solvent use, reproducibility, and extraction time, PLE could be recommended as a green alternative to conventional extraction methods.

\subsection{In Vitro Antioxidant Capacity of Polar D. fruticosa Leaves PLE and SLE Extracts}

The in vitro antioxidant capacity of the obtained polar extracts and the solid fractions after each extraction was assessed utilizing TPC by Folin-Ciocalteu's, the DPPH ${ }^{\bullet}$ scavenging, and the ABTS $^{\bullet+}$ decolorization assays. As reported in Table 4, the TPC in polar extracts ranged from 181.80 to $969.93 \mathrm{mg} \mathrm{GAE} / \mathrm{g}$ of extract, or 15.14-148.40 mg GAE when recalculated per gram of DW. The highest TPC values were obtained for the ethanolic extracts: 969.93 and $822.38 \mathrm{mg}$ GAE for the PLE-EtOH and the SLE-EtOH, respectively. This fraction was also the most active to scavenge ABTS ${ }^{\bullet+}$ and $\mathrm{DPPH}^{\bullet}$, amounting 111.48-166.09 and 96.83-151.81 mg TE/g DW, respectively. Similar observations were also reported in previous studies, where solvent fractionation of biomass or obtained crude extract were performed $[6,9]$. The obtained values for the SLE-EtOH extract in the DPPH and ABTS assays are in close agreement with previous publications studying ethanolic extracts of $D$. fruticosa $[7,33]$. Total phenolic content and radical scavenging capacity of acetone and water extracts were lower as compared to ethanol fractions: up to $\approx 5$ and 8-fold in PLE and SLE, respectively. Regardless of the solvent used, the efficiency of PLE to extract antioxidant compounds from $D$. fruticosa leaves was significantly higher as compared to SLE in all assays. In total, $253.83 \mathrm{mg}$ of GAE, $375.68\left(\mathrm{ABTS}^{\bullet+}\right)$, and $273.77\left(\mathrm{DPPH}^{\bullet+}\right) \mathrm{mg}$ of TE were recovered from $1 \mathrm{~g}$ of plant material after $135 \mathrm{~min}$ of 3-step PLE. Up to $38 \%$ lower cumulative TPC (175.71 mg GAE/g), TEAC ${ }_{\text {ABTS }}(232.96 \mathrm{mg} \mathrm{TE} / \mathrm{g})$, and TEAC $\mathrm{DPPH}_{\mathrm{DP}}(169.59 \mathrm{mg} \mathrm{TE} / \mathrm{g})$ values were obtained after sequential SLE in 8-fold longer time (Table 4). The evaluation of the solid fractions with the QUENCHER approach verified the successful recovery of the vast majority ( $\approx 98 \%$ ) of antioxidant substances from $D$. fruticosa leaves. The TPC and TEAC values of residues after final consecutive extraction step were 3.12-3.91 mg GAE and 1.18-3.50 mg TE per $1 \mathrm{~g}$ of DW (Table 4). This contributes to only $\approx 2 \%$ of TPC and radical scavenging activity of the initial plant material (Table 1 ). To the best of our knowledge, this is the first report on the systematic and comprehensive evaluation of the total antioxidant capacity of $D$. fruticosa.3.4. UPLC-ESI-TOF-MS Analysis of D. fruticosa Leaves PLE Extracts.

\subsection{UPLC-ESI-TOF-MS Analysis of D. fruticosa Leaves PLE Extracts}

Previous studies have shown that $D$. fruticosa contains a wide range of bioactive substances. Flavonoids and their glycosides, hydrolyzed tannins, sterols, triterpenoids, and phenolic acids have been previously reported [6-8,34]. According to the review of Tomczyk and Latté, the high tannin levels, and to a lesser extent triterpenes present in different anatomical parts of Dasiphora genera, are responsible for the majority of the reported pharmacological effects both in vitro and in vivo [8]. A preliminary qualitative phytochemical composition of the three different polarity PLE extracts, obtained under optimal conditions reported in this study is presented in Table 5. 


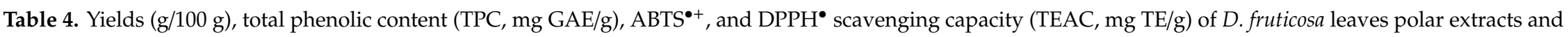
solid residues after sequential pressurized liquid extraction (PLE) and solid-liquid extraction (SLE) with acetone, ethanol, and water.

\begin{tabular}{|c|c|c|c|c|c|c|c|}
\hline \multirow{2}{*}{ Sample } & \multirow{2}{*}{$\begin{array}{c}\text { Yield, } \\
\text { g/100 g DW }\end{array}$} & \multicolumn{2}{|c|}{ TPC } & \multicolumn{2}{|c|}{ TEAC $_{\text {ABTS }}$} & \multicolumn{2}{|c|}{ TEAC $_{\text {DPPH }}$} \\
\hline & & mg GAE/g Sample ${ }^{2}$ & $\mathrm{mg} \mathrm{GAE} / \mathrm{g}$ DW $^{1}$ & mg TE/g Sample ${ }^{2}$ & mg TE/g DW ${ }^{1}$ & mg TE/g Sample ${ }^{2}$ & ${\mathrm{mg} \mathrm{TE} / \mathrm{g} \mathrm{DW}^{1}}^{1}$ \\
\hline \multicolumn{8}{|c|}{ Polar extracts (from the residue after SFE- $\mathrm{CO}_{2}$ ) } \\
\hline \multicolumn{8}{|c|}{ Sequential high-pressure extraction ${ }^{3}$ : } \\
\hline PLE-Ac $\left(62^{\circ} \mathrm{C}, 45 \mathrm{~min}\right)$ & $11.38 \pm 0.12^{\mathrm{c}}$ & $650.87 \pm 16.45^{\mathrm{f}}$ & $74.07 \pm 1.87^{\mathrm{e}}$ & $1402.01 \pm 41.39^{\mathrm{f}}$ & $159.55 \pm 4.71^{\mathrm{g}}$ & $758.57 \pm 16.88^{f}$ & $86.33 \pm 1.92^{\mathrm{e}}$ \\
\hline PLE-EtOH $\left(75^{\circ} \mathrm{C}, 45 \mathrm{~min}\right)$ & $15.30 \pm 0.33^{e}$ & $969.93 \pm 18.57^{h}$ & $148.40 \pm 2.84 \mathrm{~g}$ & $1085.59 \pm 30.45^{\mathrm{e}}$ & $166.09 \pm 4.66^{g}$ & $992.25 \pm 16.01^{\mathrm{h}}$ & $151.81 \pm 2.45^{\mathrm{i}}$ \\
\hline PLE- $\mathrm{H}_{2} \mathrm{O}\left(130^{\circ} \mathrm{C}, 45 \mathrm{~min}\right)$ & $13.76 \pm 0.44^{\mathrm{d}}$ & $227.91 \pm 5.05^{\mathrm{d}}$ & $31.36 \pm 0.69 \mathrm{~cd}$ & $363.65 \pm 7.34^{\mathrm{c}}$ & $50.04 \pm 1.01^{\mathrm{d}}$ & $258.96 \pm 6.09^{d}$ & $35.63 \pm 0.84^{c}$ \\
\hline \multicolumn{8}{|c|}{ Sequential conventional extraction ${ }^{4}$ : } \\
\hline SLE-Ac $\left(40^{\circ} \mathrm{C}, 360 \mathrm{~min}\right)$ & $6.79 \pm 0.02^{\mathrm{a}}$ & $565.62 \pm 10.11^{\mathrm{e}}$ & $38.39 \pm 0.69^{d}$ & $1533.87 \pm 89.22 \mathrm{~g}$ & $104.10 \pm 6.05^{\mathrm{e}}$ & $837.62 \pm 24.76^{g}$ & $56.85 \pm 1.68^{\mathrm{d}}$ \\
\hline SLE-EtOH $\left(60^{\circ} \mathrm{C}, 360 \mathrm{~min}\right)$ & $14.86 \pm 0.04^{\mathrm{e}}$ & $822.38 \pm 23.85 \mathrm{~g}$ & $122.18 \pm 3.54^{\mathrm{f}}$ & $750.34 \pm 21.55^{d}$ & $111.48 \pm 3.20^{\mathrm{e}}$ & $651.75 \pm 22.41^{\mathrm{e}}$ & $96.83 \pm 3.33^{f}$ \\
\hline SLE- $\mathrm{H}_{2} \mathrm{O}\left(60^{\circ} \mathrm{C}, 360 \mathrm{~min}\right)$ & $8.33 \pm 0.02^{b}$ & $181.80 \pm 11.65^{c}$ & $15.14 \pm 0.97^{b}$ & $208.75 \pm 10.90^{b}$ & $17.38 \pm 0.91^{b}$ & $191.08 \pm 4.82^{\mathrm{c}}$ & $15.91 \pm 0.40^{\mathrm{b}}$ \\
\hline \multicolumn{8}{|c|}{ Solid fractions (from the residue after SFE- $\mathrm{CO}_{2}$ ): } \\
\hline \multicolumn{8}{|c|}{ Sequential high-pressure extraction ${ }^{3}$ : } \\
\hline Residue after PLE-Ac & 86.16 * & $187.11 \pm 9.68^{c}$ & $161.21 \pm 8.34^{\mathrm{h}}$ & $149.41 \pm 5.82^{b}$ & $128.73 \pm 5.02^{\mathrm{f}}$ & $136.91 \pm 11.18^{b}$ & $117.96 \pm 9.63^{h}$ \\
\hline Residue after PLE-Ac-EtOH & $70.86^{* *}$ & $36.17 \pm 1.98^{b}$ & $25.57 \pm 1.40^{c}$ & $43.46 \pm 1.69^{\mathrm{a}}$ & $30.79 \pm 1.20^{c}$ & $23.40 \pm 0.62^{\mathrm{a}}$ & $16.58 \pm 0.44^{b}$ \\
\hline $\begin{array}{c}\text { Residue after } \\
\text { PLE-Ac-EtOH- } \mathrm{H}_{2} \mathrm{O}\end{array}$ & $57.10^{* * *}$ & $5.46 \pm 0.03^{a}$ & $3.12 \pm 0.02^{a}$ & $2.34 \pm 0.12^{a}$ & $1.34 \pm 0.07^{a}$ & $2.07 \pm 0.17^{\mathrm{a}}$ & $1.18 \pm 0.10^{\mathrm{a}}$ \\
\hline \multicolumn{8}{|c|}{ Sequential conventional extraction ${ }^{4}$ : } \\
\hline Residue after SLE-Ac & $90.75 *$ & $177.20 \pm 5.28^{c}$ & $160.81 \pm 4.79^{h}$ & $136.39 \pm 1.24^{b}$ & $123.77 \pm 1.12^{\mathrm{f}}$ & $117.82 \pm 6.26^{b}$ & $106.92 \pm 5.68 \mathrm{~g}$ \\
\hline Residue after SLE-Ac-EtOH & $75.89^{* *}$ & $34.55 \pm 0.59^{b}$ & $26.22 \pm 0.45^{c}$ & $25.67 \pm 1.52^{\mathrm{a}}$ & $19.48 \pm 1.15^{b}$ & $22.59 \pm 2.07^{\mathrm{a}}$ & $17.15 \pm 1.57^{\mathrm{b}}$ \\
\hline $\begin{array}{c}\text { Residue after } \\
\text { SLE-Ac-EtOH- } \mathrm{H}_{2} \mathrm{O}\end{array}$ & $67.56^{* * *}$ & $5.79 \pm 0.06^{\mathrm{a}}$ & $3.91 \pm 0.04^{a}$ & $3.50 \pm 0.27^{a}$ & $2.36 \pm 0.18^{\mathrm{a}}$ & $2.32 \pm 0.21^{\mathrm{a}}$ & $1.57 \pm 0.14^{\mathrm{a}}$ \\
\hline
\end{tabular}


Table 5. Qualitative phytochemical characterization of D. fruticosa leaves semi-polar and polar extracts after sequential pressurized liquid extraction (PLE) with acetone, ethanol, and water.

\begin{tabular}{|c|c|c|c|c|c|c|c|c|c|}
\hline \multirow{2}{*}{$\begin{array}{l}\text { R.T, } \\
\text { min }\end{array}$} & \multirow{2}{*}{$\begin{array}{c}\text { Meas. Mass, } \\
\qquad m / z\end{array}$} & \multirow{2}{*}{$\Delta$-ppm } & \multirow{2}{*}{$\begin{array}{l}\text { Suggested } \\
\text { Formula }\end{array}$} & \multirow{2}{*}{ Adduct } & \multirow{2}{*}{ Tentative Identification } & \multicolumn{3}{|c|}{ PLE Extracts } & \multirow{2}{*}{ Reference } \\
\hline & & & & & & PLE-Ac & PLE-EtOH & $\mathrm{PLE}_{-} \mathrm{H}_{2} \mathrm{O}$ & \\
\hline $0.3-0.4$ & 179.0560 & 0 & $\mathrm{C}_{6} \mathrm{H}_{11} \mathrm{O}_{6}$ & $\mathrm{M}-\mathrm{H}$ & monosaccharide & + & + & + & \\
\hline $0.3-0.4$ & 195.0511 & 0 & $\mathrm{C}_{6} \mathrm{H}_{11} \mathrm{O}_{7}$ & $\mathrm{M}-\mathrm{H}$ & gluconic acid & - & - & + & \\
\hline $0.3-0.4$ & 215.0325 & 11 & $\mathrm{C}_{12} \mathrm{H}_{8} \mathrm{O}_{4}$ & $\mathrm{M}-\mathrm{H}$ & bergapten & + & + & - & \\
\hline $0.3-0.4$ & 269.0877 & 21 & $\mathrm{C}_{15} \mathrm{H}_{9} \mathrm{O}_{5}$ & $\mathrm{M}-\mathrm{H}$ & apigenin & + & - & - & [35] \\
\hline $0.3-0.4$ & 387.1143 & 14 & $\mathrm{C}_{20} \mathrm{H}_{19} \mathrm{O}_{8}$ & $\mathrm{M}-\mathrm{H}$ & unknown flavonoid & + & + & + & \\
\hline $0.4-0.4$ & 191.0562 & 0 & $\mathrm{C}_{7} \mathrm{H}_{11} \mathrm{O}_{6}$ & $\mathrm{M}-\mathrm{H}$ & quinic acid & - & + & + & \\
\hline $0.4-0.4$ & 341.1086 & 0 & $\mathrm{C}_{12} \mathrm{H}_{21} \mathrm{O}_{11}$ & $\mathrm{M}-\mathrm{H}$ & disaccharide & + & + & - & \\
\hline $0.4-0.4$ & 377.0854 & 6 & $\mathrm{C}_{18} \mathrm{H}_{17} \mathrm{O}_{9}$ & $\mathrm{M}-\mathrm{H}$ & unknown & - & + & - & \\
\hline $0.4-0.5$ & 133.0142 & 0 & $\mathrm{C}_{4} \mathrm{H}_{5} \mathrm{O}_{5}$ & $\mathrm{M}-\mathrm{H}$ & malic acid & - & - & + & \\
\hline $0.6-0.6$ & 481.0622 & 0 & $\mathrm{C}_{20} \mathrm{H}_{17} \mathrm{O}_{14}$ & $\mathrm{M}-\mathrm{H}$ & quercetin-glucuronopyranoside & - & - & + & {$[6,36]$} \\
\hline $0.7-0.8$ & 191.0198 & 0 & $\mathrm{C}_{6} \mathrm{H}_{7} \mathrm{O}_{7}$ & $\mathrm{M}-\mathrm{H}$ & citric acid & - & - & + & \\
\hline $0.9-0.9$ & 217.0354 & 0 & $\mathrm{C}_{7} \mathrm{H}_{3} \mathrm{~N}_{7} \mathrm{O}_{2}$ & $\mathrm{M}-\mathrm{H}$ & unknown & - & - & + & \\
\hline $1.0-1.0$ & 169.0142 & 0 & $\mathrm{C}_{7} \mathrm{H}_{5} \mathrm{O}_{5}$ & $\mathrm{M}-\mathrm{H}$ & gallic acid & - & - & + & {$[37,38]$} \\
\hline $1.6-1.7$ & 483.0784 & 0 & $\mathrm{C}_{20} \mathrm{H}_{19} \mathrm{O}_{14}$ & $\mathrm{M}-\mathrm{H}$ & digalloyl glycoside & - & + & - & \\
\hline $1.7-1.8$ & 289.0718 & 0 & $\mathrm{C}_{15} \mathrm{H}_{13} \mathrm{O}_{6}$ & $\mathrm{M}-\mathrm{H}$ & catechin & + & + & + & {$[6,9]$} \\
\hline $1.7-1.8$ & 353.0877 & 0 & $\mathrm{C}_{16} \mathrm{H}_{17} \mathrm{O}_{9}$ & $\mathrm{M}-\mathrm{H}$ & chlorogenic acid & - & + & + & [39] \\
\hline $1.7-1.8$ & 579.1507 & 0 & $\mathrm{C}_{30} \mathrm{H}_{27} \mathrm{O}_{12}$ & $\mathrm{M}-\mathrm{H}$ & unknown flavonoid glycoside & + & + & - & \\
\hline $1.7-1.8$ & 643.1667 & 0 & $\mathrm{C}_{31} \mathrm{H}_{31} \mathrm{O}_{15}$ & $\mathrm{M}-\mathrm{H}_{2} \mathrm{O}$ & kaempferol glycoside & - & + & - & \\
\hline $1.8-1.9$ & 291.0148 & 1 & $\mathrm{C}_{13} \mathrm{H}_{7} \mathrm{O}_{8}$ & $\mathrm{M}-\mathrm{H}$ & unknown & - & - & + & \\
\hline $1.9-2.0$ & 165.0193 & 0 & $\mathrm{C}_{8} \mathrm{H}_{5} \mathrm{O}_{4}$ & $\mathrm{M}-\mathrm{H}$ & hydroxybenzoic acid & + & + & - & \\
\hline $1.9-2.0$ & 327.1083 & 0 & $\mathrm{C}_{15} \mathrm{H}_{19} \mathrm{O}_{8}$ & $\mathrm{M}-\mathrm{H}$ & luteolin-trimethyl ether & + & + & - & [40] \\
\hline $1.9-2.0$ & 577.1347 & 0 & $\mathrm{C}_{30} \mathrm{H}_{25} \mathrm{O}_{12}$ & $\mathrm{M}-\mathrm{H}$ & apigenin-(coumaroyl)-glucoside (terniflorin) & + & + & + & [41] \\
\hline $1.9-2.0$ & 635.0889 & 0 & $\mathrm{C}_{27} \mathrm{H}_{23} \mathrm{O}_{18}$ & $\mathrm{M}-\mathrm{H}$ & gallotannin & + & + & - & \\
\hline $1.9-2.0$ & 865.1980 & 0 & $\mathrm{C}_{30} \mathrm{H}_{26} \mathrm{O}_{13}$ & $\mathrm{M}-\mathrm{H}$ & unknown & + & - & - & \\
\hline $2.2-2.3$ & 576.1272 & 0 & $\mathrm{C}_{30} \mathrm{H}_{26} \mathrm{O}_{13}$ & $\mathrm{M}-\mathrm{H}_{2} \mathrm{O}$ & unknown flavonoid glycoside & + & - & - & \\
\hline $2.2-2.3$ & 609.1458 & 0 & $\mathrm{C}_{27} \mathrm{H}_{29} \mathrm{O}_{16}$ & $\mathrm{M}-\mathrm{H}$ & quercetin-rutinoside (rutin) & + & + & - & {$[6,36]$} \\
\hline $2.2-2.3$ & 615.0988 & 0 & $\mathrm{C}_{28} \mathrm{H}_{23} \mathrm{O}_{16}$ & $\mathrm{M}-\mathrm{H}$ & unknown flavonoid glycoside & + & + & - & - \\
\hline $2.3-2.3$ & 463.0880 & 0 & $\mathrm{C}_{21} \mathrm{H}_{19} \mathrm{O}_{12}$ & $\mathrm{M}-\mathrm{H}$ & quercetin-galactoside (hyperoside) & + & + & + & {$[7,9,33,36]$} \\
\hline $2.3-2.4$ & 300.9987 & 0 & $\mathrm{C}_{14} \mathrm{H}_{5} \mathrm{O}_{8}$ & $\mathrm{M}-\mathrm{H}$ & ellagic acid & + & + & + & {$[6,9]$} \\
\hline $2.3-2.4$ & 477.0674 & 0 & $\mathrm{C}_{21} \mathrm{H}_{17} \mathrm{O}_{13}$ & $\mathrm{M}-\mathrm{H}$ & quercetin-galacturonide/-glucuronide & + & + & + & \\
\hline
\end{tabular}


Table 5. Cont.

\begin{tabular}{|c|c|c|c|c|c|c|c|c|c|}
\hline \multirow{2}{*}{$\begin{array}{l}\text { R.T, } \\
\text { min }\end{array}$} & \multirow{2}{*}{$\begin{array}{c}\text { Meas. Mass, } \\
m / z\end{array}$} & \multirow{2}{*}{$\Delta$-ppm } & \multirow{2}{*}{$\begin{array}{l}\text { Suggested } \\
\text { Formula }\end{array}$} & \multirow{2}{*}{ Adduct } & \multirow{2}{*}{ Tentative Identification } & \multicolumn{3}{|c|}{ PLE Extracts } & \multirow{2}{*}{ Reference } \\
\hline & & & & & & PLE-Ac & PLE-EtOH & $\mathrm{PLE} \mathrm{H}_{2} \mathrm{O}$ & \\
\hline $2.5-2.6$ & 319.0456 & 1 & $\mathrm{C}_{15} \mathrm{H}_{11} \mathrm{O}_{8}$ & $\mathrm{M}-\mathrm{H}$ & dihydromyricetin & - & + & - & \\
\hline $2.6-2.7$ & 433.0771 & 0 & $\mathrm{C}_{20} \mathrm{H}_{17} \mathrm{O}_{11}$ & $\mathrm{M}-\mathrm{H}$ & quercetin-arabinofuranoside (avicularin) & + & + & - & {$[41]$} \\
\hline $2.6-2.7$ & 451.1035 & 0 & $\mathrm{C}_{24} \mathrm{H}_{19} \mathrm{O}_{9}$ & $\mathrm{M}-\mathrm{H}$ & epigallocatechin-coumarate & + & - & - & \\
\hline 3.1-3.1 & 485.1094 & 0 & $\mathrm{C}_{24} \mathrm{H}_{21} \mathrm{O}_{11}$ & $\mathrm{M}-\mathrm{H}$ & epigallocatechin-dimethylgallate & - & + & - & \\
\hline $3.1-3.1$ & 521.0856 & 15 & $\mathrm{C}_{23} \mathrm{H}_{21} \mathrm{O}_{14}$ & $\mathrm{M}-\mathrm{H}$ & unknown flavonoid glycoside & - & + & - & \\
\hline $3.1-3.1$ & 614.2514 & 0 & $\mathrm{C}_{36} \mathrm{H}_{38} \mathrm{O}_{9}$ & $\mathrm{M}-\mathrm{H}$ & unknown & + & + & - & \\
\hline $3.1-3.1$ & 720.1593 & 0 & $\mathrm{C}_{38} \mathrm{H}_{28} \mathrm{~N}_{2} \mathrm{O}_{13}$ & $\mathrm{M}-\mathrm{H}$ & unknown & + & + & - & \\
\hline $3.2-3.2$ & 477.1040 & 0 & $\mathrm{C}_{22} \mathrm{H}_{21} \mathrm{O}_{12}$ & $\mathrm{M}-\mathrm{H}$ & rhamnetin-glucopyranoside & + & + & + & {$[6]$} \\
\hline $3.2-3.2$ & 593.1308 & 1 & $\mathrm{C}_{30} \mathrm{H}_{25} \mathrm{O}_{13}$ & $\mathrm{M}-\mathrm{H}$ & kaempferol-rutinoside & + & + & + & [6] \\
\hline $3.2-3.3$ & 491.0833 & 0 & $\mathrm{C}_{22} \mathrm{H}_{19} \mathrm{O}_{13}$ & $\mathrm{M}-\mathrm{H}$ & isorhamnetin-glucuronide & - & - & + & [42] \\
\hline 3.3-3.4 & 447.0938 & 1 & $\mathrm{C}_{21} \mathrm{H}_{19} \mathrm{O}_{11}$ & $\mathrm{M}-\mathrm{H}$ & quercitrin/astragalin & + & + & - & [42] \\
\hline $3.3-3.4$ & 628.267 & 0 & $\mathrm{C}_{37} \mathrm{H}_{40} \mathrm{O}_{9}$ & $\mathrm{M}-\mathrm{H}$ & unknown & + & - & - & \\
\hline $3.9-4.0$ & 329.2336 & 0 & $\mathrm{C}_{18} \mathrm{H}_{33} \mathrm{O}_{5}$ & $\mathrm{M}-\mathrm{H}$ & tricin/rhamnatin & + & - & - & \\
\hline $5.0-5.1$ & 487.3431 & 0 & $\mathrm{C}_{30} \mathrm{H}_{47} \mathrm{O}_{5}$ & $\mathrm{M}-\mathrm{H}$ & tormentic acid & + & - & - & [43] \\
\hline $5.0-5.1$ & 533.3489 & 0 & $\mathrm{C}_{30} \mathrm{H}_{43} \mathrm{~N}_{7} \mathrm{O}_{2}$ & $\mathrm{M}-\mathrm{H}$ & unknown & + & - & - & \\
\hline $5.7-5.8$ & 485.3276 & 0 & $\mathrm{C}_{30} \mathrm{H}_{45} \mathrm{O}_{5}$ & M-H & unknown & + & - & - & \\
\hline $5.7-5.8$ & 531.3332 & 0 & $\mathrm{C}_{31} \mathrm{H}_{47} \mathrm{O}_{7}$ & $\mathrm{M}-\mathrm{H}$ & unknown & + & - & - & \\
\hline $6.3-6.3$ & 471.3483 & 0 & $\mathrm{C}_{30} \mathrm{H}_{47} \mathrm{O}_{4}$ & $\mathrm{M}-\mathrm{H}$ & hydroxyursolic acid & + & - & - & [43] \\
\hline $6.3-6.3$ & 517.3537 & 0 & $\mathrm{C}_{31} \mathrm{H}_{49} \mathrm{O}_{6}$ & M-H & unknown & + & - & - & \\
\hline $6.3-6.3$ & 943.7025 & 1 & $\mathrm{C}_{60} \mathrm{H}_{95} \mathrm{O}_{8}$ & $\mathrm{M}-\mathrm{H}$ & glycerolipid & + & - & - & \\
\hline
\end{tabular}

+: Detected; -: not detected; Ac: acetone; EtOH: ethanol; PLE: pressurized liquid extraction. 
Tentative identification of substances was ascribed based on a comparison of the obtained chromatographic data (suggested formula and accurate mass measurement) with previously identified compounds in the literature of Dasiphora genera and available mass spectral databases such as Metlin. In total, 39 out of a total 50 peaks present in the PLE extracts could be tentatively assigned to specific structures (Table 5). For example, the peak eluting at $2.3 \mathrm{~min}$, which was present in all three extracts, showed an experimental $\mathrm{m} / \mathrm{z}$ of 463.088 and a suggested deprotonated formula of $\mathrm{C}_{21} \mathrm{H}_{19} \mathrm{O}_{12}$ could be tentatively ascribed to the quercetin-galactoside (hyperoside). Not surprisingly, many previous studies reported that hyperoside was the predominant, or one of the primary compounds, in various anatomical parts $D$. fruticosa, including leaves $[7,33,36]$. This flavonoid glycoside has been reported to exert multiple bioactive properties. Anti-inflammatory and anti-redox activities, myocardial protection, and inhibition of osteosarcoma proliferation have been reported for hyperoside [44]. Another substance (R.T 2.3-2.4 min, $m / z=300.9987$, suggested formula $\mathrm{C}_{14} \mathrm{H}_{5} \mathrm{O}_{8}$ ), also present in all obtained extracts, can be ascribed to ellagic acid, a commonly reported bioactive substance of $D$. fruticosa. Epidemiological studies indicate that intake of foods that are rich in ellagic acid or ellagitannins, which under physiological conditions in vivo are hydrolyzed to ellagic acid, can be protective against chronic diseases such as certain types of cancer [45]. Several other structures could be assigned to glycosylated apigenin, quercetin, rhamnetin, and kaempferol (Table 5). Recent epidemiological data indicate health-protective properties against chronic diseases like neurodegenerative, cardiovascular diseases, diabetes, and osteoporosis by the consumption of products rich in dietary flavonoids $[46,47]$. Except for flavonoids and tannins, the chromatographic analysis also indicated the presence of certain triterpenoids, among which are tormentic acid $\left(m / z=487.3431, \mathrm{C}_{30} \mathrm{H}_{47} \mathrm{O}_{5}\right)$ and hydroxyursolic acid $\left(m / z=471.3483, \mathrm{C}_{30} \mathrm{H}_{47} \mathrm{O}_{4}\right)$. Pentacyclic triterpenoids, play a critical role in the management and treatment and of non-communicable diseases like diabetes mellitus, cancer, chronic respiratory, and cardiovascular diseases [48].

\section{Conclusions}

This study outlined the efficacy and potential of high-pressure techniques such as $\mathrm{SFE}-\mathrm{CO}_{2}$ and PLE for the recovery of antioxidant-rich fractions from $D$. fruticosa leaves. Central composite design and response surface methodology were successfully applied to optimize critical extraction parameters, such as temperature and time. The influence of extraction parameters on process yield and total phenolic content was presented, and the optimal extraction conditions were suggested. The application of sequential high-pressure extraction resulted in higher extraction yields and in significantly shorter times than the conventional alternatives. The in vitro antioxidant capacity of obtained extracts indicated that $D$. fruticosa leaf extracts contain substances with high radical scavenging capacity. Phytochemical characterization of the high-pressure extracts revealed the presence of potent natural antioxidants, such as hyperoside, ellagic acid, and triterpenoids. In conclusion, the results of this study highlight the potential of sequential high-pressure extraction as a simple and efficient alternative for the recovery of natural antioxidants from $D$. fruticosa leaves, a promising source of bioactive compounds for food nutraceutical and pharmaceutical applications.

Supplementary Materials: The following are available online at http://www.mdpi.com/2076-3921/9/6/457/s1. Table S1: Analysis of variance of the regression parameters for the PLE-Ac response surface quadratic model of $D$. fruticosa leaves for the response factors PLE-Ac extract yield $\left(\mathrm{g} / 100 \mathrm{~g}\right.$ of residue after $\left.\mathrm{SFE}_{\mathrm{CO}} \mathrm{CO}_{2}\right)$ and total phenolic content (mg GAE/g of residue after SFE- $\mathrm{CO}_{2}$ ). Table S2: Analysis of variance of the regression parameters for the PLE-EtOH response surface quadratic model of $D$. fruticosa leaves for the response factors PLE-EtOH extract yield (g/100 g of residue after PLE-Ac) and total phenolic content (mg GAE/g of residue after PLE-Ac). Figure S1: Schematic representation of sequential non-polar and polar constituent isolation from $D$. fruticosa leaves applying high-pressure and conventional extraction techniques. Figure S2: Pareto chart $(p=0.05)$ for the main effects of PLE-Ac temperature $(\mathrm{T})$ and time $(\tau)$ and interactions thereof on the total extraction yield $(\mathrm{g} / 100 \mathrm{~g}$ residue after $\mathrm{SFE}-\mathrm{CO}_{2}$ ) and total phenolic content (TPC, mg GAE/g residue after $\mathrm{SFE}-\mathrm{CO}_{2}$ ). Figure S3: Pareto chart $(p=0.05)$ for the main effects of PLE-EtOH temperature $(\mathrm{T})$ and time $(\tau)$ and interactions thereof on the total extraction yield ( $\mathrm{g} / 100 \mathrm{~g}$ residue after PLE-Ac) and total phenolic content (TPC, $\mathrm{mg}$ GAE/g residue after PLE-Ac). 
Author Contributions: Conceptualization, M.S., and P.R.V.; methodology, K.S. and V.K.; validation, M.S., K.S., and V.K.; formal analysis, M.S. and K.S.; investigation, M.S., K.S., and V.K.; resources, P.R.V.; data curation, M.S. and P.R.V.; writing—original draft preparation, M.S. and V.K.; writing-review and editing, M.S., V.K. and P.R.V.; visualization, K.S., and V.K.; supervision, M.S. and P.R.V.; project administration, P.R.V. All authors have read and agreed to the published version of the manuscript.

Funding: This research received no external funding.

Acknowledgments: The authors would like to thank Ona Ragažinskienè (Kaunas Botanical Garden of Vytautas Magnus University) for supplying plant material and Rita Kazernavičiūte (Department of Food Science and Technology, Kaunas University of Technology) for her assistance with the fatty acid profile analyses.

Conflicts of Interest: The authors declare no conflict of interest.

\section{References}

1. Saeidnia, S.; Abdollahi, M. Toxicological and pharmacological concerns on oxidative stress and related diseases. Toxicol. Appl. Pharmacol. 2013, 273, 442-455. [CrossRef] [PubMed]

2. Li, A.-N.; Li, S.; Zhang, Y.-J.; Xu, X.-R.; Chen, Y.-M.; Li, H.-B. Resources and biological activities of natural polyphenols. Nutrients 2014, 6, 6020-6047. [CrossRef] [PubMed]

3. Silva, R.F.M.; Pogačnik, L. Polyphenols from food and natural products: Neuroprotection and safety. Antioxidants 2020, 9, 61. [CrossRef] [PubMed]

4. Mlcek, J.; Rop, O. Fresh edible flowers of ornamental plants-A new source of nutraceutical foods. Trends Food Sci. Technol. 2011, 22, 561-569. [CrossRef]

5. Miliauskas, G.; Venskutonis, P.R.; van Beek, T.A. Screening of radical scavenging activity of some medicinal and aromatic plant extracts. Food Chem. 2004, 85, 231-237. [CrossRef]

6. Miliauskas, G.; van Beek, T.A.; Venskutonis, P.R.; Linssen, J.P.H.; de Waard, P.; Sudhölter, E.J. Antioxidant activity of Potentilla fruticosa. J. Sci. Food Agric. 2004, 84, 1997-2009. [CrossRef]

7. Wang, S.-S.; Wang, D.-M.; Pu, W.-J.; Li, D.-W. Phytochemical profiles, antioxidant and antimicrobial activities of three Potentilla species. BMC Complement. Altern. Med. 2013, 13, 321. [CrossRef] [PubMed]

8. Tomczyk, M.; Latté, K.P. Potentilla-A review of its phytochemical and pharmacological profile. J. Ethnopharmacol. 2009, 122, 184-204. [CrossRef] [PubMed]

9. Luo, Z.; Wang, S.; Wang, D. Phenolic profiles and antioxidant capacities of crude extracts and subsequent fractions from Potentilla fruticosa L. leaves. Nat. Prod. Res. 2016, 30, 1890-1895. [CrossRef] [PubMed]

10. Jurkštienė, V.; Pavilonis, A.; Garšvienė, D.; Juozulynas, A.; Samsonienè, L.; Daukšienè, D.; Jankauskienė, K.; Šimonienè-Kazlauskienè, G.; Stankevičius, E. Investigation of the antimicrobial activity of rhaponticum (rhaponticum carthamoides D.C. iljin) and shrubby cinquefoil (Potentilla fruticosa L.). Med. Buenos Aires 2011, 47, 24. [CrossRef]

11. $\mathrm{Pu}$, W.J.; Li, D.W.; Wang, D.M. Potentilla fruticosa extracts as antimicrobials in post-harvest storage of fruits. Allelopath. J. 2014, 34, 59-70.

12. Liu, Z.; Luo, Z.; Jia, C.; Wang, D.; Li, D. Synergistic effects of Potentilla fruticosa L. leaves combined with green tea polyphenols in a variety of oxidation systems. J. Food Sci. 2016, 81, C1091-C1101. [CrossRef] [PubMed]

13. Liu, Z.-H.; Wang, D.-M.; Fan, S.-F.; Li, D.-W.; Luo, Z.-W. Synergistic effects and related bioactive mechanism of Potentilla fruticosa L. leaves combined with Ginkgo biloba extracts studied with microbial test system (MTS). BMC Complement. Altern. Med. 2016, 16, 495. [CrossRef] [PubMed]

14. Wang, S.; Wang, D.; Liu, Z. Synergistic, additive and antagonistic effects of Potentillafruticosa combined with EGb761 on antioxidant capacities and the possible mechanism. Ind. Crop. Prod. 2015, 67, 227-238. [CrossRef]

15. Cavaiuolo, M.; Cocetta, G.; Ferrante, A. The antioxidants changes in ornamental flowers during development and senescence. Antioxidants 2013, 2, 132-155. [CrossRef]

16. Liu, W.; Wang, D.; Hou, X.; Yang, Y.; Xue, X.; Jia, Q.; Zhang, L.; Zhao, W.; Yin, D. Effects of growing location on the contents of main active components and antioxidant activity of dasiphora fruticosa (L.) rydb. by chemometric methods. Chem. Biodivers. 2018, 15, e1800114. [CrossRef]

17. Liu, W.; Yin, D.; Li, N.; Hou, X.; Wang, D.; Li, D.; Liu, J. Influence of environmental factors on the active substance production and antioxidant activity in potentilla fruticosa L. and its quality assessment. Sci. Rep. 2016, 6, 28591. [CrossRef] 
18. Huie, C.W. A review of modern sample-preparation techniques for the extraction and analysis of medicinal plants. Anal. Bioanal. Chem. 2002, 373, 23-30. [CrossRef]

19. Xu, D.-P.; Li, Y.; Meng, X.; Zhou, T.; Zhou, Y.; Zheng, J.; Zhang, J.-J.; Li, H.-B. Natural antioxidants in foods and medicinal plants: Extraction, assessment and resources. Int. J. Mol. Sci. 2017, 18, 96. [CrossRef]

20. Bendif, H.; Adouni, K.; Miara, M.D.; Baranauskienè, R.; Kraujalis, P.; Venskutonis, P.R.; Nabavi, S.M.; Maggi, F. Essential oils (EOs), pressurized liquid extracts (PLE) and carbon dioxide supercritical fluid extracts $\left(\mathrm{SFE}-\mathrm{CO}_{2}\right)$ from Algerian Thymus munbyanus as valuable sources of antioxidants to be used on an industrial level. Food Chem. 2018, 260, 289-298. [CrossRef]

21. Kemzūraitè, A.; Venskutonis, P.R.; Baranauskienè, R.; Navikienè, D. Optimization of supercritical $\mathrm{CO}_{2}$ extraction of different anatomical parts of lovage (Levisticum officinale Koch.) using response surface methodology and evaluation of extracts composition. J. Supercrit. Fluids 2014, 87, 93-103. [CrossRef]

22. Grauzdytè, D.; Pukalskas, A.; El Kalamouni, C.; Venskutonis, P.R. Antioxidant potential and phytochemical composition of extracts obtained from Phyllanthus phillyreifolius by different extraction methods. Nat. Prod. Res. 2020, 34, 706-709. [CrossRef]

23. Singleton, V.L.; Orthofer, R.; Lamuela-Raventós, R.M. Analysis of total phenols and other oxidation substrates and antioxidants by means of folin-ciocalteu reagent. Methods Enzymol. 1998, 299, 152-178.

24. Re, R.; Pellegrini, N.; Proteggente, A.; Pannala, A.; Yang, M.; Rice-Evans, C. Antioxidant activity applying an improved ABTS radical cation decolorization assay. Free Radic. Biol. Med. 1999, 26, 1231-1237. [CrossRef]

25. Brand-Williams, W.; Cuvelier, M.E.; Berset, C. Use of a free radical method to evaluate antioxidant activity. LWT-Food Sci. Technol. 1995, 28, 25-30. [CrossRef]

26. Gökmen, V.; Serpen, A.; Fogliano, V. Direct measurement of the total antioxidant capacity of foods: The 'QUENCHER' approach. Trends Food Sci. Technol. 2009, 20, 278-288. [CrossRef]

27. Kitrytė, V.; Narkevičiūtè, A.; Tamkutè, L.; Syrpas, M.; Pukalskienè, M.; Venskutonis, P.R. Consecutive high-pressure and enzyme assisted fractionation of blackberry (Rubus fruticosus L.) pomace into functional ingredients: Process optimization and product characterization. Food Chem. 2020, 312, 126072. [CrossRef] [PubMed]

28. Kitrytè, V.; Laurinavičienè, A.; Syrpas, M.; Pukalskas, A.; Venskutonis, P.R. Modeling and optimization of supercritical carbon dioxide extraction for isolation of valuable lipophilic constituents from elderberry (Sambucus nigra L.) pomace. J. $\mathrm{CO}_{2}$ Util. 2020, 35, 225-235. [CrossRef]

29. Syrpas, M.; Bukauskaitè, J.; Paškauskas, R.; Bašinskienė, L.; Venskutonis, P.R. Recovery of lipophilic products from wild cyanobacteria (Aphanizomenon flos-aquae) isolated from the Curonian Lagoon by means of supercritical carbon dioxide extraction. Algal Res. 2018, 35, 10-21. [CrossRef]

30. Azmir, J.; Zaidul, I.S.M.; Rahman, M.M.; Sharif, K.M.; Mohamed, A.; Sahena, F.; Jahurul, M.H.A.; Ghafoor, K.; Norulaini, N.A.N.; Omar, A.K.M. Techniques for extraction of bioactive compounds from plant materials: A review. J. Food Eng. 2013, 117, 426-436. [CrossRef]

31. Kas'yanov, G.I.; Shaftan, É.A.; Klimova, E.S. An investigation of $\mathrm{CO}_{2}$ extracts from the roots and rhizomes of Potentilla erecta and Archangelica officinalis. Chem. Nat. Compd. 1977, 13, 94-95.

32. Giacometti, J.; Bursać Kovačević, D.; Putnik, P.; Gabrić, D.; Bilušić, T.; Krešić, G.; Stulić, V.; Barba, F.J.; Chemat, F.; Barbosa-Cánovas, G.; et al. Extraction of bioactive compounds and essential oils from mediterranean herbs by conventional and green innovative techniques: A review. Food Res. Int. 2018, 113, 245-262. [CrossRef] [PubMed]

33. Yu, D.; Pu, W.; Li, D.; Wang, D.; Liu, Q.; Wang, Y. Phenolic compounds and antioxidant activity of different organs of Potentilla fruticosa L. from two main production areas of China. Chem. Biodivers. 2016, 13, 1140-1148. [CrossRef] [PubMed]

34. Tomczyk, M.; Pleszczyńska, M.; Wiater, A. Variation in total polyphenolics contents of aerial parts of potentilla species and their anticariogenic activity. Molecules 2010, 15, 4639-4651. [CrossRef]

35. Xue, P.; Zhao, Y.; Wang, B.; Liang, H. Simultaneous determination of seven flavonoids in potentilla multifida by HPLC. J. Chromatogr. Sci. 2007, 45, 216-219. [CrossRef]

36. Tomczyk, M.; Bazylko, A.; Bonarewicz, J. Method development and validation for optimized separation of quercetin derivatives in selected Potentilla species using high-performance thin-layer chromatography photodensitometry method. J. Pharm. Biomed. Anal. 2012, 61, 265-270. [CrossRef]

37. Xue, P.-F.; Zhao, Y.-Y.; Wang, B.; Liang, H. Secondary metabolites from Potentilla discolor Bunge (Rosaceae). Biochem. Syst. Ecol. 2006, 34, 825-828. [CrossRef] 
38. Gao, W.; Shen, Y.; Zhang, H.-J.; Tang, H.; Lin, H.-W.; Qiu, F. The chemical constituents of Potentilla chinensis. Pharm. Care Res. 2007, 7, 262-264.

39. Okuda, T.; Yoshida, T.; Hatano, T.; Iwasaki, M.; Kubo, M.; Orime, T.; Yoshizaki, M.; Naruhashi, N. Hydrolysable tannins as chemotaxonomic markers in the rosaceae. Phytochemistry 1992, 31, 3091-3096. [CrossRef]

40. Wollenweber, E.; Dörr, M. Flavonoid aglycones from the lipophilic exudates of some species of Rosaceae. Biochem. Syst. Ecol. 2008, 36, 481-483. [CrossRef]

41. Ganenko, T.V.; Lutskii, B.I.; Larin, M.F.; Vereshchagin, A.L.; Semenov, A.A. Chemical composition of Potentilla fruticosa. I. Flavonoids. Chem. Nat. Compd. 1988, 24, 387-388. [CrossRef]

42. Kombal, R.; Glasl, H. Flavan-3-ols and flavonoids from Potentilla anserina. Planta Med. 1995, 61, 484-485. [CrossRef] [PubMed]

43. Ganenko, T.V.; Semenov, A.A. Chemical composition of Potentilla fruticosa. II. Triterpenoids. Chem. Nat. Compd. 1989, 25, 727. [CrossRef]

44. Zhang, N.; Ying, M.-D.; Wu, Y.-P.; Zhou, Z.-H.; Ye, Z.-M.; Li, H.; Lin, D.-S. Hyperoside, a flavonoid compound, inhibits proliferation and stimulates osteogenic differentiation of human osteosarcoma cells. PLoS ONE 2014, 9, e98973. [CrossRef]

45. Landete, J.M. Ellagitannins, ellagic acid and their derived metabolites: A review about source, metabolism, functions and health. Food Res. Int. 2011, 44, 1150-1160. [CrossRef]

46. Fernandes, I.; Pérez-Gregorio, R.; Soares, S.; Mateus, N.; de Freitas, V. Wine flavonoids in health and disease prevention. Molecules 2017, 22, 292. [CrossRef]

47. Rees, A.; Dodd, G.; Spencer, J. The effects of flavonoids on cardiovascular health: A review of human intervention trials and implications for cerebrovascular function. Nutrients 2018, 10, 1852. [CrossRef]

48. Mlala, S.; Oyedeji, A.O.; Gondwe, M.; Oyedeji, O.O. Ursolic acid and its derivatives as bioactive agents. Molecules 2019, 24, 2751. [CrossRef]

(C) 2020 by the authors. Licensee MDPI, Basel, Switzerland. This article is an open access article distributed under the terms and conditions of the Creative Commons Attribution (CC BY) license (http://creativecommons.org/licenses/by/4.0/). 